\title{
Modeling and prediction of sulfuric acid digestion analyses data from PXRF spectrometry
}

\section{in tropical soils}

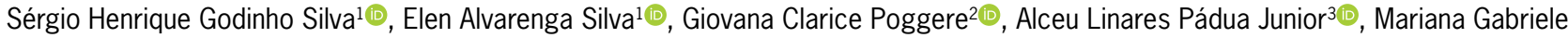

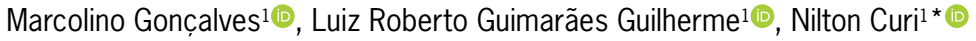

\author{
${ }^{1}$ Universidade Federal de Lavras - Depto. de Ciência do \\ Solo, C.P. 3037 - 37200-000 - Lavras, MG - Brasil. \\ 2Universidade Tecnológica Federal do Paraná - Depto. de \\ Ciências Biológicas e Ambientais - Campus Medianeira, Av. \\ Brasil, 4232 - Independência - 84884-000 - Medianeira, \\ PR - Brasil. \\ 3Universidade Federal dos Vales do Jequitinhonha e Mucuri/ \\ Instituto de Ciências Agrárias - Campus Unaí, Av. Vereador \\ João Narciso, 1380 - Cachoeira - 38610-000 - Unaí, MG \\ - Brasil. \\ *Corresponding author <niltcuri@ufla.br>
}

Edited by: Tiago Osório Ferreira

Received April 26, 2018

Accepted January 10, 2019
ABSTRACT: Sulfuric acid digestion analyses (SAD) provide useful information to environmental studies, in terms of the geochemical balance of nutrients, parent material uniformity, nutrient reserves for perennial crops, and mineralogical composition of the soil clay fraction. Yet, these analyses are costly, time consuming, and generate chemical waste. This work aimed at predicting SAD results from portable X-ray fluorescence ( $p X R F$ ) spectrometry, which is proposed as a "green chemistry" alternative to the current SAD method. Soil samples developed from different parent materials were analyzed for soil texture and SAD, and scanned with pXRF. The SAD results were predicted from pXRF elemental analyses through simple linear regressions, stepwise multiple linear regressions, and random forest algorithm, with and without incorporation of soil texture data. The modeling was developed with $70 \%$ of the data, while the remaining $30 \%$ was used for validation through calculation of $R^{2}$, adjusted $R^{2}$, root mean square error, and mean error. Simple linear regression can accurately predict SAD results of $\mathrm{Fe}_{2} \mathrm{O}_{3}\left(\mathrm{R}^{2}\right.$ 0.89), $\mathrm{TiO}_{2}\left(\mathrm{R}^{2} 0.96\right)$ and $\mathrm{P}_{2} \mathrm{O}_{5}\left(\mathrm{R}^{2}\right.$ 0.89). Stepwise regressions provided accurate predictions for $\mathrm{Al}_{2} \mathrm{O}_{3}\left(\mathrm{R}^{2}\right.$ 0.87) and $\mathrm{Ki}$ - molar weathering index $\left(\mathrm{SiO}_{2} / \mathrm{Al}_{2} \mathrm{O}_{3}\right)\left(\mathrm{R}^{2} \mathrm{0.74}\right)$ by incorporating soil texture data, as well as for $\mathrm{SiO}_{2}\left(\mathrm{R}^{2} 0.61\right)$. Random forest also provided adequate predictions, especially for $\mathrm{Fe}_{2} \mathrm{O}_{3}\left(\mathrm{R}^{2} \mathrm{0.95}\right)$, and improved results of $\mathrm{Kr}$ - molar weathering index $\left(\mathrm{SiO}_{2} /\left(\mathrm{Al}_{2} \mathrm{O}_{3}+\mathrm{Fe}_{2} \mathrm{O}_{3}\right)\right)\left(\mathrm{R}^{2} \mathrm{0.66}\right)$, by incorporation of soil texture data. Our findings showed that the $\mathrm{SAD}$ results could be accurately predicted from $\mathrm{pXRF}$ data, decreasing costs, time and the production of laboratory waste.

Keywords: soil clay fraction, weathering indices, random forest, proximal sensors, green chemistry

\section{Introduction}

Applied research using portable X-ray fluorescence (pXRF) spectrometry has increased dramatically over the last few years in different fields of Soil Science (Duda et al., 2017; Chakraborty et al., 2017; Silva et al., 2017; Stockmann et al., 2016). Weindorf et al. (2014) suggested that, in the future, great efforts will be made to establish correlations between pXRF data and results of conventional laboratorial analyses.

Recent studies have used pXRF data to predict various soil chemical and physical properties resulted from conventional laboratory analyses (Aldabaa et al., 2015; Sharma et al., 2014; Sharma et al., 2015; Silva et al., 2017; Zhu et al., 2011). This means that, analyses that are costly, difficult to be performed, time-consuming, and that generate chemical residues could be replaced or at least reduced, if accurate predictions of their results are achieved from pXRF data (Rouillon and Taylor, 2016; McGladdery et al., 2018).

In Brazil, sulfuric acid digestion analyses (SAD) are important for studies concerning geochemical balance of nutrients, parent material uniformity, nutrient reserves for perennial crops, as well as mineralogical composition of the soil clay fraction, among others (Curi and Kämpf, 2012). These analyses provide contents of some elements expressed on the oxide basis $\left(\mathrm{Al}_{2} \mathrm{O}_{3}, \mathrm{SiO}_{2}, \mathrm{Fe}_{2} \mathrm{O}_{3}, \mathrm{TiO}_{2}\right.$, and $\mathrm{P}_{2} \mathrm{O}_{5}$ ). Furthermore, this data allows calculating two indi- ces used in the Brazilian Soil Classification System and in soil surveys to differentiate highly weathered soils, that is, $\mathrm{Ki}\left(\mathrm{SiO}_{2} / \mathrm{Al}_{2} \mathrm{O}_{3}\right)$ and $\mathrm{Kr}\left(\mathrm{SiO}_{2} /\left(\mathrm{Al}_{2} \mathrm{O}_{3}+\mathrm{Fe}_{2} \mathrm{O}_{3}\right)\right)$. However, conventional SAD is expensive, time-consuming, and generates considerable amounts of chemical waste. In an attempt to overcome this issue, Silva et al. (2018) used pXRF to estimate SAD results applying simple linear regression, obtaining accurate predictions only for $\mathrm{Fe}_{2} \mathrm{O}_{3}$ and $\mathrm{TiO}_{2}$. Nevertheless, several more robust statistical models have been used in other studies, generating suitable results, such as multiple linear regressions (Rourke et al., 2016; Forkuor et al., 2017) and random forest algorithm (Chagas et al., 2016; Souza et al., 2016; Silva et al., 2017).

Considering that SAD determines the chemical composition of fine fractions (clay fraction mainly) and that pXRF determines the soil bulk chemical composition, we hypothesize that the results of soil bulk chemical composition determined by $\mathrm{pXRF}$ could be well correlated with SAD results in tropical soils, allowing the replacement of SAD by prediction models using $\mathrm{pXRF}$ data as input variables. In this sense, this study aimed at predicting the results of SAD from pXRF data, applying simple and multiple linear regressions as well as random forest algorithm. We expect not only to reduce cost, time and laboratory waste, but also to facilitate the use of SAD-derived information in studies on tropical soils. 


\section{Materials and Methods}

\section{Soil sampling and laboratory analyses}

This study was conducted using 52 soil samples collected from the southern, southeastern, and northeastern regions of Brazil, encompassing four states, 19 soil classes according to Soil Taxonomy (Soil Survey Staff, 2014) and 14 parent materials (Table 1).

Soils were morphologically described, and samples from A and B horizons were collected for laboratory analyses. The soil texture analyses were performed according to Baver et al. (1972) and Gee and Bauder (1986). For SAD (Embrapa, 1997), $1 \mathrm{~g}$ of soil was mixed with 500 $\mathrm{mL}$ of sulfuric acid and $500 \mathrm{~mL}$ of water. Then, the solution was boiled for 30 min followed by addition of 50 $\mathrm{mL}$ of water. This mixture was filtered and the $\mathrm{Fe}_{2} \mathrm{O}_{3}$ and $\mathrm{Al}_{2} \mathrm{O}_{3}$ contents were determined by titration, whereas $\mathrm{TiO}_{2}$ and $\mathrm{P}_{2} \mathrm{O}_{5}$ contents were determined by colorimetry, and $\mathrm{SiO}_{2}$, by gravimetry. From these results, weathering indices $\left[\mathrm{Ki}=\mathrm{SiO}_{2} / \mathrm{Al}_{2} \mathrm{O}_{3}\right.$ and $\left.\mathrm{Kr}=\mathrm{SiO}_{2} /\left(\mathrm{Al}_{2} \mathrm{O}_{3}+\mathrm{Fe}_{2} \mathrm{O}_{3}\right)\right]$ were calculated.

\section{pXRF analyses}

Soil samples from A and B horizons were air-dried, ground and sieved through a 2-mm mesh (air-dried fine earth, ADFE). Next, about $15 \mathrm{~g}$ of ADFE were analyzed by $\mathrm{pXRF}$ spectrometry, in the Trace (dual soil) mode, during $60 \mathrm{~s}$, in triplicate, using the Geochem software, as recommended by Weindorf and Chakraborty (2016). This equipment has a Rh X-ray tube, $50 \mathrm{keV}, 100 \mu \mathrm{A}$, and a silicon drift detector (SDD) with resolution of $<145$ $\mathrm{eV}$, which allows detection of several chemical elements, from Mg to U (Weindorf et al., 2014; Ribeiro et al., 2017). The pXRF performance was checked through scanning reference materials (CRM) certified by National Institute of Standards and Technology (NIST) (2710a and 2711a) and a sample certified by the equipment manufacturer for the elements detected in most samples. The values recovered $(100 \times \mathrm{pXRF}$ results/certified results) for these elements in comparison to information from CRM 2710a and 2711a and the manufacturer's sample, were $\mathrm{Al}_{2} \mathrm{O}_{3}$ (84/65/91), $\mathrm{Fe}$ (81/66/85), $\mathrm{SiO}_{2}(64 / 47 / 85), \mathrm{P}_{2} \mathrm{O}_{5}(381 / 547 /-)$, $\mathrm{Ti}(82 / 69 /-), \mathrm{K}_{2} \mathrm{O}(60 / 47 / 89), \mathrm{Cr}(-/ 112 /-), \mathrm{Mn}(74 / 59 / 85), \mathrm{Ni}$ (-/96/101), Ca (40/46/-), Cu (-/77/92), Zn (-/85/-), V (51/27/1, $\mathrm{Zr} \mathrm{(-/105/-),} \mathrm{Rb}(104 / 102 /-)$, and $\mathrm{Pb}(107 / 108 / 104)$, respectively. Lack of recovery values indicates that either a certified concentration of that element was not available in the reference sample or the pXRF was not able to detect that element. It is worth mentioning that the results of pXRF may be influenced by particle size, moisture content, scanning time, interelemental interference, and atomic weight (Peinado et al., 2010; Weindorf et al., 2014; Ribeiro et al., 2017), which may explain some low recovery values for some elements.

\section{Statistical analyses}

Simple linear regressions were generated between the pXRF elemental results and elemental results from
$\mathrm{SAD}$, such as pXRF $\mathrm{Al}_{2} \mathrm{O}_{3}$ to predict $\mathrm{SAD} \mathrm{Al}_{2} \mathrm{O}_{3}$. Similarly, weathering indices were calculated from both SAD and $\mathrm{pXRF}$ results and simple linear regressions were adjusted between them.

Contrary to the procedure to adjust simple linear regression models, when only $\mathrm{pXRF}$ data equivalent to the elements provided by $\mathrm{SAD}\left(\mathrm{Al}_{2} \mathrm{O}_{3}, \mathrm{SiO}_{2}, \mathrm{Fe}_{2} \mathrm{O}_{3}, \mathrm{TiO}_{2}\right.$, and $\mathrm{P}_{2} \mathrm{O}_{5}$ ) were used, stepwise multiple linear regressions were created to predict SAD results based on all the elements detected by pXRF for all samples, that is, $\mathrm{Al}_{2} \mathrm{O}_{3}, \mathrm{Fe}, \mathrm{SiO}_{2}, \mathrm{P}_{2} \mathrm{O}_{5}, \mathrm{Ti}, \mathrm{K}_{2} \mathrm{O}, \mathrm{Cr}, \mathrm{Mn}, \mathrm{Ni}, \mathrm{Cu}, \mathrm{Zn}$, allowing the generation of more robust models. Furthermore, two regression models per element resulted from SAD were created varying the datasets, as follows: a) using only pXRF data; and, b) using pXRF data in addition to soil texture data of each sample (sand, silt, and clay contents). In this case, we adopted the backward stepwise method in which the least important variables for the model were removed. The addition of soil texture data may improve predictions, due to relationships found between the mineral composition of the soil and the particle size fraction in which each mineral is commonly found. Quartz $\left(\mathrm{SiO}_{2}\right)$ is the main mineral found in the sand fraction of tropical soils, while most clay particles correspond to kaolinite and Fe- and Al-oxides (Kämpf et al., 2012).

The random forest algorithm was applied to predict the SAD results as well as weathering indices through the same elements used in stepwise multiple linear regression. Random forest was performed in $\mathrm{R}$ software, through the random Forest package (Liaw and Wiener, 2015). The number of trees grown by the model was 1000 , the number of variables used per node was 5 , and the number of variables inserted per tree was four, which is $1 / 3$ of the total number of predictors, as suggested by Liaw and Wiener (2002). The model provides the mean square of residuals OOB (out-of-bag), the percentage of variance explained by the model, and the importance of each variable for the model (Breiman, 2001; Liaw and Wiener, 2002). Similar to stepwise multiple linear regressions, random forest models were created with different datasets: a) only pXRF data; and, b) pXRF data in association with sand, silt, and clay contents of each sample.

For the generation of models through linear regressions, stepwise multiple linear regressions, and random forest algorithm, the total database was separated into two datasets: 37 samples $(70 \%)$ for the creation of models, and 15 samples (30\%) for validation of the generated models to ensure that they provide accurate predictions of SAD results and weathering indices through pXRF data.

\section{Validation}

The predicted values resulted from the linear regressions, stepwise multiple linear regressions, and random forest models were compared with the observed values through calculations of $\mathrm{R}^{2}$, adjusted $\mathrm{R}^{2}\left(\mathrm{R}^{2}{ }_{\text {adj }}\right)$, root 
Table 1 - Soils, parent material, location, number of samples (n), soil horizon, texture and results of sulfuric acid digestion analysis.

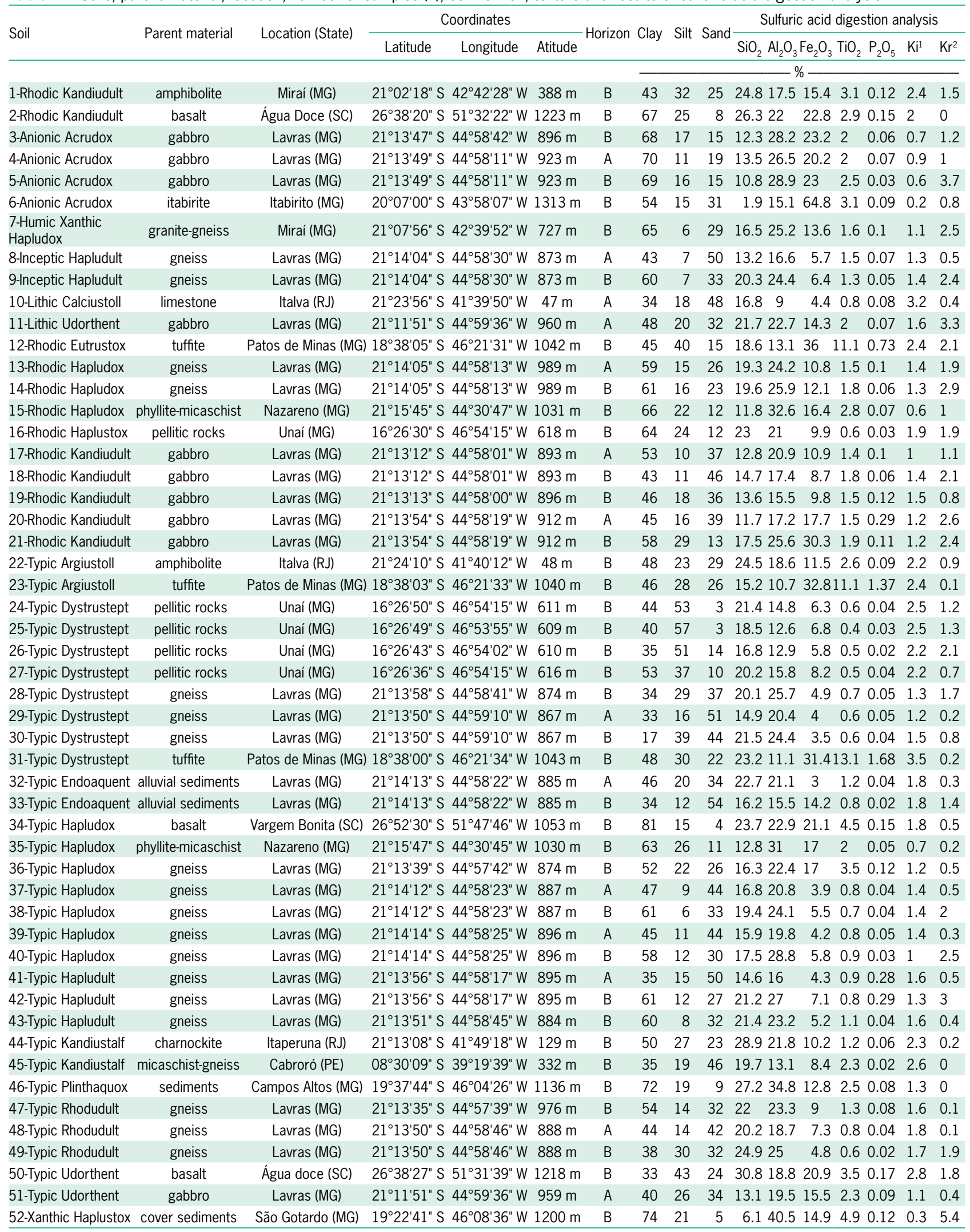

${ }^{1} \mathrm{Ki}=\mathrm{SiO}_{2} / \mathrm{Al}_{2} \mathrm{O}_{3} ;{ }^{2 \mathrm{Kr}}=\mathrm{SiO}_{2} /\left(\mathrm{Al}_{2} \mathrm{O}_{3}+\mathrm{Fe}_{2} \mathrm{O}_{3}\right)$. 
mean square error (RMSE) (Equation 1), and mean error (ME) (Equation 2). The greater the $\mathrm{R}^{2}$ and $\mathrm{R}^{2}{ }_{\text {adj' }}$ and the lower the RMSE and ME, the more accurate the prediction models, considering the defined parameter. Then, the best method was determined to calculate the content of each element, as well as to predict weathering indices resulted from SAD.

$$
R M S E=\sqrt{\frac{1}{n} \sum_{i=1}^{n}(e i-m i)^{2}}
$$

$$
M E=\frac{1}{n} \sum_{i=1}^{n}(e i-m i)
$$

where $n$ : number of observations; ei: values estimated by the model; and mi: values obtained through SAD.

\section{Results and Discussion}

\section{Soil chemical attributes}

The range of SAD values result from different factors of soil formation (Tables 1,2, and 3), similar to values found for other soils from other regions of Brazil /Curi and Franzmeier, 1987; Vasconcelos et al., 2013; Santos et al., 2014; Carvalho Filho et al., 2015). Soils developed from itabirite, basalt, gabbro, and tuffite presented the highest $\mathrm{Fe}_{2} \mathrm{O}_{3}$ and $\mathrm{TiO}_{2}$ contents and the lowest $\mathrm{SiO}_{2}$ contents. $\mathrm{Fe}_{2} \mathrm{O}_{3}$ and $\mathrm{TiO}_{2}$ decrease and $\mathrm{SiO}_{2}$ increases as the parent material becomes felsic, with greater quartz amounts, such as soils derived from gneiss. The lowest $\mathrm{Fe}_{2} \mathrm{O}_{3}$ contents were found in the Typic Endoaquent, due to the reduction of $\mathrm{Fe}^{3+}$ to $\mathrm{Fe}^{2+}$ followed by solubilization of Fe-bearing minerals (Schaetzl and Anderson, 2005) and $\mathrm{Fe}^{2+}$ leaching.

$\mathrm{Fe}_{2} \mathrm{O}_{3}, \mathrm{Al}_{2} \mathrm{O}_{3}$, and $\mathrm{P}_{2} \mathrm{O}_{5}$ pXRF contents were lower or greater than those found for SAD according to soil mineralogy and, hence, soil texture, which presented a wide variation for the studied soils due to the diversity of parent materials and weathering degree of soils (Table 4). For $\mathrm{Al}_{2} \mathrm{O}_{3}$ and $\mathrm{P}_{2} \mathrm{O}_{5}, 75$ and $77 \%$ of the samples, respectively, presented SAD contents greater than those obtained by pXRF. The opposite trend was observed for $\mathrm{SiO}_{2}, \mathrm{Fe}_{2} \mathrm{O}_{3}$, and $\mathrm{TiO}_{2}$, which presented 73, 63, and 67 $\%$ of the samples with pXRF contents greater than SAD contents. The SAD analyses are more likely to provide the digestion of clay-sized particles (Curi and Kämpf, 2012). Since Brazilian soils have large contents of $\mathrm{SiO}_{2}$ in the sand fraction, mainly as quartz (Brinatti et al., 2010; Kämpf et al., 2012), the $\mathrm{SiO}_{2}$ content is only accessed by pXRF, justifying its larger content than that found with $\mathrm{SAD}$, similar to the results for $\mathrm{Fe}_{2} \mathrm{O}_{3}$ and $\mathrm{TiO}_{2}$, which are components of minerals also occurring in the sand fraction, such as magnetite, rutile, and ilmenite (Kämpf et al., 2012). Since higher contents of $\mathrm{Al}$ and $\mathrm{P}$ are commonly found in the clay fraction (Brinatti et al., 2010), these contents obtained through SAD were higher than those obtained with $\mathrm{pXRF}$.

\section{Simple linear regression modeling and predictions}

Table 5 presents the values of $\mathrm{R}^{2}, \mathrm{R}_{\text {adj }}$ and the equations obtained by simple linear regressions between SAD and pXRF data. For the predictions of $\mathrm{Fe}_{2} \mathrm{O}_{3}, \mathrm{TiO}_{2}$, and $\mathrm{P}_{2} \mathrm{O}_{5}, \mathrm{R}^{2}$ and $\mathrm{R}_{\text {adj }}$ values were higher than 0.80 , showing an adequate fit of these regressions for the prediction of these SAD results directly from pXRF data.

The prediction of $\mathrm{Fe}_{2} \mathrm{O}_{3}$ had the highest $\mathrm{R}^{2}$ and $\mathrm{R}^{2}{ }_{\text {adj }}$ followed by $\mathrm{P}_{2} \mathrm{O}_{5}$. It is noteworthy that SAD quantifies mostly the elemental contents in the clay fraction (Resende et al., 1987; Curi and Kämpf, 2012). Consequently, since $\mathrm{Fe}_{2} \mathrm{O}_{3}$ of tropical soils is concentrated in this fraction due to the high weathering degree of these soils, the contents obtained by pXRF should be well correlated to those from SAD. However, $\mathrm{Fe}_{2} \mathrm{O}_{3}$ is also present in the form of magnetite in the sand fraction (Schaefer et al., 2008). Thus, the presence of this mineral in this fraction may have prevented an even better adjustment.

For $\mathrm{Al}_{2} \mathrm{O}_{3}$ and $\mathrm{SiO}_{2}$, adequate adjustments were not possible. Conversely, the $\mathrm{Ki}$ and $\mathrm{Kr}$ indices had $\mathrm{R}^{2}$ of 0.59 and 0.53 , respectively. Possible reasons for SAD $\mathrm{Al}_{2} \mathrm{O}_{3}$ and $\mathrm{SiO}_{2}$ predictions not to be viable include the frequent occurrence of quartz $\left(\mathrm{SiO}_{2}\right)$ and some presence of phyllosilicates (containing both $\mathrm{Al}$ and $\mathrm{Si}$, among other elements) in the sand fraction of Brazilian soils. Again, as SAD quantifies mainly the elemental content of the clay fraction (Resende et al., 1987), portions of Si and Al detected by $\mathrm{pXRF}$ were not quantified by SAD, hindering an adequate fit of linear regressions between these values. Another factor that may have influenced the adjustment of these prediction models is the low recovery values obtained for $\mathrm{Si}$ and $\mathrm{Al}$, probably due to factors that influence the pXRF analysis, such as particle size, moisture, sample weight, sample preparation, data collection, and instrument alignment (Weindorf et al., 2014; Silva et al., 2018; Santana et al., 2018; Ribeiro et al., 2018; Peinado et al., 2010), although the samples of this study were analyzed in similar conditions regarding these influencing factors. In fact, this may be a constraint to the pXRF analysis if such factors are not taken into account.

In contrast, the equations generated to predict SAD $\mathrm{Fe}_{2} \mathrm{O}_{3}, \mathrm{TiO}_{2}$, and $\mathrm{P}_{2} \mathrm{O}_{5}$ from the contents obtained by pXRF were validated (Figure 1 ). $\mathrm{TiO}_{2}$ obtained $\mathrm{R}^{2}$ and $\mathrm{R}_{\text {adj }}$ of 0.96 with very low values of RMSE and ME. $\mathrm{P}_{2} \mathrm{O}_{5}$ and $\mathrm{Fe}_{2} \mathrm{O}_{3}$ presented an $\mathrm{R}^{2}$ of 0.89 . For $\mathrm{P}_{2} \mathrm{O}_{5}$, the $\mathrm{ME}$ and RMSE values were low, whereas for $\mathrm{Fe}_{2} \mathrm{O}_{3}$ the RMSE values were the highest among all elements (Figure 1) due to the greater range of $\mathrm{Fe}_{2} \mathrm{O}_{3}$ contents.

These results confirm the possibility of using pXRF to predict $\mathrm{Fe}_{2} \mathrm{O}_{3}, \mathrm{TiO}_{2}$, and $\mathrm{P}_{2} \mathrm{O}_{5}$ contents of SAD. In a preliminary study, only $\mathrm{Fe}_{2} \mathrm{O}_{3}$ and $\mathrm{TiO}_{2}$ yielded adequate fit values for linear regressions (Silva et al., 2018). Santana et al. (2018) found adequate results for predicting $\mathrm{SAD} \mathrm{Fe} \mathrm{O}_{3}$ and $\mathrm{TIO}_{2}$ for Brazilian soils. In this study, this trend was confirmed in addition to an adequate adjustment for $\mathrm{P}_{2} \mathrm{O}_{5}$ contents, which has not been previously reported. 
Table 2 - Portable X-ray fluorescence (pXRF) spectrometry data for A- and B-horizon samples of the soils studied.

\begin{tabular}{|c|c|c|c|c|c|c|c|c|c|c|c|c|c|c|c|c|c|c|}
\hline Soil & Hor. & $\mathrm{SiO}_{2}$ & $\mathrm{Al}_{2} \mathrm{O}_{3}$ & $\mathrm{Fe}_{2} \mathrm{O}_{3}$ & $\mathrm{TiO}_{2}$ & $\mathrm{P}_{2} \mathrm{O}_{5}$ & $\mathrm{~K}_{2} \mathrm{O}$ & $\mathrm{Cl}$ & $\mathrm{CaO}$ & $\mathrm{Cr}$ & $\mathrm{Cu}$ & $\mathrm{Mn}$ & $\mathrm{Ni}$ & $\mathrm{Pb}$ & $\mathrm{Rb}$ & V & $\mathrm{Zn}$ & $\mathrm{Zr}$ \\
\hline & & & & & & & & & & & & & & & & & & \\
\hline Rhodic Kandiudult & B & 23.6 & 11.6 & 15 & 3 & 0.04 & 0.18 & 487 & 292 & 419 & 35 & 296 & 100 & 8 & 8 & 155 & 29 & 197 \\
\hline 2-Rhodic Kandiudult & B & 24.4 & 11.8 & 21.1 & 3.8 & 0.05 & 0.20 & 191 & 0 & 0 & 196 & 1254 & 0 & 50 & 23 & 473 & 79 & 262 \\
\hline 3-Anionic Acrudox & B & 11.7 & 17.4 & 27.8 & 2.2 & 0 & 0.09 & 269 & 0 & 4832 & 79 & 42 & 388 & 60 & 13 & 454 & 48 & 175 \\
\hline Anionic Acrudox & A & 14.7 & 17.2 & 22.1 & 1.9 & 0.03 & 0.09 & 198 & 662 & 3631 & 61 & 341 & 328 & 37 & 4 & 354 & 45 & 158 \\
\hline 5-Anionic Acrudox & B & 12.6 & 17.6 & 23.6 & 1.7 & 0 & 0.08 & 482 & 0 & 3631 & 63 & 100 & 323 & 46 & 3 & 296 & 39 & 155 \\
\hline -Anionic Acrudox & B & 3.6 & 7.1 & 51.1 & 5.3 & 0 & 0.07 & 281 & 0 & 0 & 15 & 737 & 0 & 325 & 93 & 293 & 0 & 432 \\
\hline 7-Humic Xanthic Hapludox & B & 23.6 & 19.6 & 15.4 & 1.9 & 0.02 & 0.13 & 185 & 178 & 186 & 28 & 138 & 19 & 8 & 6 & 72 & 40 & 312 \\
\hline 3-Inceptic Hapludult & A & 34.3 & 19.1 & 7.7 & 1.6 & 0.07 & 0.19 & 668 & 883 & 111 & 32 & 807 & 18 & 0 & 0 & 113 & 34 & 225 \\
\hline Inceptic Hapludult & B & 27.3 & 28.2 & 8.8 & 1.4 & 0.05 & 0.16 & 427 & 590 & 192 & 38 & 173 & 20 & 7 & 2 & 213 & 32 & 197 \\
\hline O-Lithic Calciustoll & A & 29.5 & 9.1 & 5.6 & 0.9 & 0.1 & 0.30 & 313 & 55229 & 73 & 25 & 1114 & 36 & 18 & 20 & 21 & 40 & 166 \\
\hline 11-Lithic Udorthent & A & 27.6 & 15.7 & 15 & 1.8 & 0.06 & 0.35 & 354 & 3341 & 201 & 80 & 1532 & 52 & 10 & 17 & 221 & 68 & 158 \\
\hline 2-Rhodic Eutrustox & B & 16.8 & 8.3 & 30.7 & 16.9 & 0.14 & 0.53 & 0 & 603 & 0 & 206 & 1850 & 349 & 86 & 50 & 307 & 77 & 1764 \\
\hline 13-Rhodic Hapludox & A & 23.5 & 19 & 12.8 & 2 & 0.02 & 0.19 & 482 & 1237 & 272 & 38 & 336 & 31 & 8 & 5 & 90 & 25 & 217 \\
\hline 4-Rhodic Hapludox & B & 19.5 & 16.1 & 13.8 & 2.1 & 0 & 0.22 & 725 & 126 & 271 & 36 & 347 & 39 & 17 & 2 & 0 & 24 & 214 \\
\hline 5-Rhodic Hapludox & B & 12.8 & 20.8 & 19.8 & 3.1 & 0 & 0.09 & 520 & 0 & 382 & 25 & 222 & 0 & 19 & 3 & 223 & 13 & 279 \\
\hline 16-Rhodic Haplustox & B & 32.8 & 13.8 & 9.4 & 1.8 & 0.07 & 1.33 & 571 & 658 & 48 & 35 & 118 & 27 & 27 & 152 & 40 & 22 & 298 \\
\hline 17-Rhodic & A & 25.5 & 16.2 & 13.5 & 1.8 & 0.05 & 0.33 & 638 & 1174 & 1542 & 38 & 713 & 195 & 9 & 15 & 1 & 41 & 242 \\
\hline 18-Rhodic Kandiudult & B & 31.2 & 17.6 & 10.6 & 1.7 & 0.1 & 0.41 & 220 & 1133 & 956 & 34 & 1497 & 201 & 19 & 15 & 89 & 44 & 228 \\
\hline 19-Rhodic Kandiudult & B & 18.6 & 10.7 & 9 & 1.1 & 0.03 & 0.25 & 489 & 6906 & 814 & 28 & 546 & 144 & 9 & 5 & 9 & 32 & 200 \\
\hline 20-Rhodic Kandiudult & A & 21.7 & 12.7 & 19 & 1.4 & 0.08 & 0.42 & 354 & 2546 & 1597 & 67 & 656 & 117 & 35 & 22 & 72 & 47 & 130 \\
\hline 21-Rhodic Kandiudult & B & 14.7 & 14.4 & 28.5 & 1.8 & 0 & 0.08 & 254 & 599 & 3131 & 147 & 790 & 346 & 66 & 15 & 404 & 70 & 137 \\
\hline 22-Typic Argiustoll & B & 28.5 & 13.4 & 11.7 & 1.9 & 0.02 & 0.13 & 98 & 6117 & 107 & 36 & 585 & 124 & 20 & 9 & 71 & 38 & 208 \\
\hline 23-Typic Argiustoll & B & 14.6 & 5.2 & 24.5 & 17.2 & 0.45 & 0.67 & 0 & 4979 & 0 & 245 & 1972 & 371 & 47 & 104 & 0 & 124 & 1937 \\
\hline 24-Typic & B & 50.9 & 10.3 & 5.5 & 1.1 & 0.12 & 2.74 & 529 & 2048 & 57 & 27 & 198 & 2 & 9 & 140 & 1 & 47 & 179 \\
\hline 25-Typic Dystrustept & B & 48.2 & 9.5 & 6.6 & 1.1 & 0.11 & 2.55 & 538 & 3123 & 77 & 29 & 523 & 20 & 7 & 133 & 60 & 51 & 189 \\
\hline 26-Typic Dystrustept & B & 51.7 & 11.3 & 4.3 & 1 & 0.08 & 2.74 & 900 & 904 & 55 & 27 & 139 & 22 & 0 & 131 & 8 & 41 & 207 \\
\hline 27-Typic Dystrustept & B & 38.5 & 11.7 & 8 & 1.3 & 0.08 & 1.66 & 413 & 1772 & 63 & 31 & 123 & $2 \varepsilon$ & 8 & 146 & 22 & 26 & 276 \\
\hline 28-Typic Dystrustept & B & 26.7 & 21.6 & 6.8 & 0.9 & 0.02 & 0.48 & 806 & 805 & 236 & 16 & 49 & 96 & 23 & 8 & 0 & 53 & 190 \\
\hline 29-Typic Dystrustept & A & 38.7 & 22.1 & 5.2 & 0.8 & 0.03 & 0.47 & 314 & 0 & 215 & 16 & 221 & 5 & 6 & 10 & 1 & 35 & 172 \\
\hline 30-Typic Dystrustept & B & 35.9 & 30.4 & 4.8 & 0.6 & 0 & 0.83 & 560 & 457 & 102 & 15 & 43 & 89 & 6 & 7 & 40 & 56 & 155 \\
\hline 31-Typic Dystrustept & B & 17 & 5.1 & 25.3 & 13.4 & 0.58 & 0.84 & 82 & 3496 & 0 & 247 & 1685 & 488 & 47 & 82 & 245 & 111 & 1425 \\
\hline 32-Typic Endoaquent & A & 38.4 & 24.1 & 3.6 & 1.2 & 0.03 & 0.33 & 361 & 575 & 390 & 23 & 114 & 6 & 9 & 7 & 122 & 33 & 256 \\
\hline 33-Typic Endoaquent & B & 41.1 & 24.4 & 1.7 & 1.1 & 0 & 0.42 & 340 & 238 & 164 & 16 & 99 & 26 & 7 & 9 & 83 & 26 & 342 \\
\hline 34-Typic Hapludox & B & 21.5 & 12.2 & 19.7 & 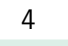 & 0.08 & 0.19 & 85 & 0 & 0 & 145 & 620 & 2 & 48 & 19 & 572 & 77 & 335 \\
\hline 35-Typic Hapludox & B & 15.5 & 18.3 & 17.6 & 2.7 & 0 & 0.07 & 363 & 0 & 30 & 27 & 266 & 7 & 19 & 0 & 233 & 10 & 198 \\
\hline 36-Typic Hapludox & B & 6.2 & 4.6 & 7.2 & 1.5 & 0 & 0.07 & 481 & 0 & 0 & 0 & 222 & 1 & 18 & 0 & 161 & 41 & 308 \\
\hline 37-Typi & A & 31.4 & 22.7 & 5.2 & 0.9 & 0.05 & 0.25 & 428 & 758 & 137 & 15 & 133 & 17 & 0 & 4 & 22 & 26 & 205 \\
\hline 38-Typic Hapludox & B & 26.7 & 25.2 & 6.7 & 0.9 & 0.06 & 0.21 & 438 & 195 & 184 & 12 & 27 & 18 & 0 & 4 & 0 & 21 & 189 \\
\hline 9-Typic Hapludox & A & 26.8 & 24.7 & 6.9 & 0.9 & 0.03 & 0.24 & 330 & 728 & 197 & 17 & 28 & 12 & 0 & 0 & 20 & 18 & 212 \\
\hline 40-Typic Hapludox & B & 23.1 & 22.9 & 7.1 & 1 & 0 & 0.23 & 607 & 237 & 159 & 14 & 76 & 16 & 0 & 2 & 0 & 19 & 220 \\
\hline 41-Typic Hapludult & A & 33.2 & 17.4 & 5.1 & 1.1 & 0.05 & 0.42 & 547 & 3902 & 54 & 18 & 690 & 3 & 30 & 12 & 0 & 31 & 292 \\
\hline 42-Typic Hapludult & B & 23.5 & 20 & 8.4 & 0.9 & 0.04 & 0.31 & 946 & 864 & 214 & 16 & 183 & 67 & 26 & 10 & 0 & 29 & 195 \\
\hline 43-Typic Hapludult & B & 28.2 & 22.1 & 7 & 1.4 & 0.02 & 0.17 & 400 & 702 & 348 & 29 & 174 & 73 & 0 & 8 & 68 & 28 & 179 \\
\hline 44-Typic Kandiustalf & B & 24 & 14.2 & 8.3 & 1 & 0 & 0.61 & 526 & 497 & 0 & 39 & 182 & 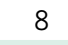 & 0 & 38 & 0 & 51 & 98 \\
\hline 45-Typic Kandiustalf & B & 33.3 & 15.8 & 10.5 & 1.6 & 0.04 & 2.24 & 498 & 5847 & 92 & 43 & 659 & 50 & 8 & 99 & 03 & 64 & 189 \\
\hline 46-Typic Plinthaquox & B & 19.8 & 22.1 & 11.4 & 4.8 & 0 & 0.08 & 328 & 151 & 0 & 31 & 300 & 27 & 29 & 0 & 249 & 33 & 540 \\
\hline 47-Typic Rhodudult & B & 23.3 & 18 & 9.5 & 1.2 & 0.04 & 0.19 & 452 & 145 & 605 & 31 & 228 & 93 & 0 & 6 & 0 & 26 & 183 \\
\hline 48-Typic Rhodudult & A & 29.3 & 17 & 7.8 & 0.6 & 0 & 0.39 & 699 & 205 & 654 & 21 & 160 & 83 & 7 & 11 & 23 & 33 & 172 \\
\hline 49-Typic Rhodudult & B & 27.8 & 21.5 & 5.8 & 0.6 & 0 & 0.46 & 586 & 0 & 364 & 19 & 0 & 71 & 6 & 8 & 0 & 28 & 140 \\
\hline 50-Typic Udorthent & B & 28.9 & 11.5 & 19.9 & 3.1 & 0.11 & 0.36 & 76 & 323 & 0 & 211 & 1590 & 14 & 27 & 41 & 434 & 135 & 213 \\
\hline 51-Typic Udorthent & A & 24.2 & 14.4 & 15.5 & 1.7 & 0.03 & 0.47 & 328 & 10293 & 229 & 99 & 1816 & 53 & 23 & 19 & 241 & 64 & 185 \\
\hline 52-Xanthic Haplustox & B & 5.1 & 23.7 & 16.1 & 6.5 & 0 & 0.07 & 271 & 0 & 0 & 15 & 283 & 0 & 8 & 0 & 488 & 10 & 683 \\
\hline
\end{tabular}


Table 3 - Maximum, minimum, and mean values of data from sulfuric acid digestion analyses (SAD) and elemental analyses by portable X-ray fluorescence ( $\mathrm{PXRF}$ ) spectrometry of $A$ - and B-horizon samples of the soils studied.

\begin{tabular}{|c|c|c|c|c|c|c|c|c|c|}
\hline & \multirow{2}{*}{$\begin{array}{l}\text { Element/ } \\
\text { Weathering } \\
\text { indices }\end{array}$} & \multicolumn{4}{|c|}{ Modeling ${ }^{1}$} & \multicolumn{4}{|c|}{ Validation $^{1}$} \\
\hline & & Min & Max & Mean & STD & Min & Max & Mean & STD \\
\hline & & \multicolumn{8}{|c|}{$\longrightarrow$ SAD $\longrightarrow$} \\
\hline \multirow{7}{*}{ Method } & $\mathrm{SiO}_{2}$ & 1.91 & 27.24 & 18.38 & 5.36 & 12.27 & 30.84 & 17.88 & 6.03 \\
\hline & $\mathrm{Al}_{2} \mathrm{O}_{3}$ & 8.99 & 40.52 & 21.50 & 6.56 & 10.74 & 31.04 & 20.61 & 6.09 \\
\hline & $\mathrm{Fe}_{2} \mathrm{O}_{3}$ & 2.97 & 64.79 & 13.66 & 11.92 & 4.25 & 32.84 & 13.18 & 8.35 \\
\hline & $\mathrm{TiO}_{2}$ & 0.47 & 13.12 & 2.29 & 2.63 & 0.36 & 11.06 & 2.11 & 2.61 \\
\hline & $\mathrm{P}_{2} \mathrm{O}_{5}$ & 0.02 & 1.68 & 0.14 & 0.29 & 0.02 & 1.37 & 0.17 & 0.34 \\
\hline & $\mathrm{Ki}$ & 0.22 & 3.59 & 1.60 & 0.73 & 0.71 & 2.82 & 1.57 & 0.7 \\
\hline & $\mathrm{Kr}$ & 0.06 & 2.45 & 1.15 & 0.48 & 0.49 & 1.85 & 1.10 & 0.47 \\
\hline & & \multicolumn{8}{|c|}{$\longrightarrow$ pXRF } \\
\hline \multirow{7}{*}{ pXRF } & $\mathrm{SiO}_{2}$ & 3.55 & 51.7 & 25.61 & 10.86 & 11.66 & 48.16 & 25.62 & 10.07 \\
\hline & $\mathrm{Al}_{2} \mathrm{O}_{3}$ & 4.60 & 30.39 & 17.09 & 6.44 & 5.24 & 21.59 & 15.29 & 4.76 \\
\hline & $\mathrm{Fe}_{2} \mathrm{O}_{3}$ & 1.69 & 51.1 & 13.08 & 9.66 & 5.06 & 27.8 & 13.33 & 7.54 \\
\hline & $\mathrm{TiO}_{2}$ & 0.56 & 16.91 & 2.64 & 3.35 & 0.58 & 17.24 & 2.63 & 4.1 \\
\hline & $\mathrm{P}_{2} \mathrm{O}_{5}$ & 0.00 & 0.58 & 0.05 & 0.1 & 0.00 & 0.45 & 0.07 & 0.11 \\
\hline & $\mathrm{Ki}$ & 0.21 & 4.93 & 1.68 & 0.99 & 0.67 & 5.05 & 1.9 & 1.14 \\
\hline & $\mathrm{Kr}$ & 0.06 & 3.30 & 0.98 & 0.68 & 0.32 & 3.41 & 1.19 & 0.78 \\
\hline
\end{tabular}

${ }^{1}$ Values calculated for $\mathrm{A}$ and $\mathrm{B}$ horizons.

Table 4 - Minimum, maximum, mean, and standard deviation values of soil texture for A- and B-horizon samples of the studied soils.

\begin{tabular}{lcccccc}
\hline & Sand & Silt & Clay & Sand & Silt & Clay \\
\hline \multicolumn{5}{c}{} & \multicolumn{3}{c}{ Modeling } & & \multicolumn{3}{c}{ Validation } \\
\hline Min & 3 & 6 & 17 & 3 & 6 & 33 \\
Max & 54 & 53 & 81 & 50 & 57 & 70 \\
Mean & 28 & 20 & 52 & 27 & 25 & 48 \\
STD & 14 & 11 & 13 & 14 & 14 & 13 \\
\hline
\end{tabular}

Table 5 - Equations, $R^{2}$, and $R_{\text {adj }}$ for prediction of sulfuric acid digestion results from elemental characterization by portable $\mathrm{X}$-ray fluorescence (pXRF) spectrometry (in ppm).

\begin{tabular}{lccl}
\hline & $\mathrm{R}^{2}$ & $\mathrm{R}_{\text {adi }}$ & \multicolumn{1}{c}{ Equations } \\
\hline $\mathrm{Al}_{2} \mathrm{O}_{3}$ & 0.29 & 0.27 & $\mathrm{Al}_{2} \mathrm{O}_{3 \text { SAD }}=12.162+0.547^{*} \mathrm{Al}_{2} \mathrm{O}_{3 \mathrm{pXRF}}$ \\
$\mathrm{SiO}_{2}$ & 0.15 & 0.12 & $\mathrm{SiO}_{2 \text { SAD }}=13.541+0.189^{*} \mathrm{SiO}_{2 \mathrm{pXRF}}$ \\
$\mathrm{P}_{2} \mathrm{O}_{5}$ & 0.83 & 0.82 & $\mathrm{P}_{2} \mathrm{O}_{5 \text { SAD }}=-0.00456+2.697^{*} \mathrm{P}_{2} \mathrm{O}_{5 \mathrm{p} \text { XRF }}$ \\
$\mathrm{Fe}_{2} \mathrm{O}_{3}$ & 0.91 & 0.91 & $\mathrm{Fe}_{2} \mathrm{O}_{3 \text { SAD }}=-1.728+1.177^{\star} \mathrm{Fe}_{2} \mathrm{O}_{3 \mathrm{pXXFF}}$ \\
$\mathrm{TiO}_{2}$ & 0.90 & 0.89 & $\mathrm{TiO}_{2 \text { SAD }}=0.328+0.745^{\star} \mathrm{TiO}_{2 \mathrm{PXRF}}$ \\
$\mathrm{Ki}$ & 0.59 & 0.58 & $\mathrm{Ki}_{\text {SAD }}=0.648+0.563^{*} \mathrm{Ki}_{\text {pXRF }}$ \\
$\mathrm{Kr}$ & 0.53 & 0.52 & $\mathrm{Ki}_{\text {SAD }}=0.641+0.513^{*} \mathrm{Kr}_{\text {pXRF }}$ \\
\hline
\end{tabular}

\section{Stepwise modeling and predictions}

The stepwise multiple linear regression method allowed the evaluation of these models to predict SAD chemical composition from $\mathrm{pXRF}$ values using additional predictors in relation to those used in the simple linear regression, that is, other $\mathrm{pXRF}$ elemental data and soil texture data. The generated models that used either $\mathrm{pXRF}$ data only or pXRF + texture data as predictor variables and their $R^{2}$ and $R_{\text {adj }}$ values are shown in Table 6 .
In the stepwise regressions, the $\mathrm{R}^{2}$ values were all above 0.79 for models without incorporation of soil texture data and above 0.83 , after incorporating texture data as predictor variables, including $\mathrm{Al}_{2} \mathrm{O}_{3}$ and $\mathrm{SiO}_{2}$, which did not yield adequate models through simple linear regression. A better adjustment of the equations when including texture data was observed for predictions of $\mathrm{SAD} \mathrm{Al}_{2} \mathrm{O}_{3}$ and $\mathrm{SiO}_{2}$. For $\mathrm{Fe}_{2} \mathrm{O}_{3}, \mathrm{TiO}_{2}, \mathrm{P}_{2} \mathrm{O}_{5}, \mathrm{Ki}$, and $\mathrm{Kr}$, models with or without soil texture data presented basically the same $\mathrm{R}^{2}$ and $\mathrm{R}^{2}$ adj values. This behavior indicates that not only texture, but also other elements provided by the pXRF analysis, in addition to $\mathrm{Fe}, \mathrm{Al}, \mathrm{Si}$, $\mathrm{P}$, and $\mathrm{Ti}$, contributed to modeling SAD results.

Regarding the pXRF elemental data, the number (in parenthesis) of models in which each element was present is: $\mathrm{Zr}(12), \mathrm{Fe}(12), \mathrm{Mn}(9), \mathrm{Al}(8), \mathrm{Ti}(8), \mathrm{Rb}(8)$, $\mathrm{Ni}(8), \mathrm{Cr}(8), \mathrm{Si}(7), \mathrm{V}(6), \mathrm{Cu}(6), \mathrm{P}(6), \mathrm{Ca}(6), \mathrm{Pb}(5)$, $\mathrm{K}(4), \mathrm{Cl}(3), \mathrm{Zn}(3)$. This fact demonstrates that some elements that now are easily accessed with pXRF may be well correlated with soil properties, facilitating the development of prediction models. Rubidium (Rb), for instance, was found to be correlated with clay content in soils from the United States by Zhu et al. (2011). Regarding the texture variables in 7 models, sand, silt, and clay were present, respectively, in 3,2, and 3 models. All the models incorporating texture data as predictor variables presented at least one size fraction in the equation, except for the Kr model, highlighting the expectations confirmed of sand presence in $\mathrm{SAD} \mathrm{SiO}_{2}$ model, while clay was one of the variables of the $\mathrm{SAD} \mathrm{Fe} \mathrm{O}_{3}$ and $\mathrm{Al}_{2} \mathrm{O}_{3}$ models, which reflects Brazilian soils mineralogy, as previously discussed.

Although the $\mathrm{Al}_{2} \mathrm{O}_{3}$ and $\mathrm{SiO}_{2}$ content did not present a good fit with simple linear regressions (Table 5), in stepwise multiple linear regressions these two elements achieved high $\mathrm{R}^{2}$ and $\mathrm{R}_{\text {adj' }}$ that is, 0.79 and 0.76 for $\mathrm{Al}_{2} \mathrm{O}_{3}$, and 0.79 and 0.71 for $\mathrm{SiO}_{2}$, with and without incorporating texture. When incorporating texture data as predictors, the model for $\mathrm{SAD} \mathrm{Al}_{2} \mathrm{O}_{3}$ included clay and silt variables, which can be explained by the weathering process and formation of kaolinite and gibbsite in greater proportion in these size fractions.

In contrast, the $\mathrm{SAD} \mathrm{SiO}_{2}$ model used sand as a variable. Quartz predominates in the sand fraction of tropical soils, which reinforces the importance of this particle size fraction for the prediction of $\mathrm{SAD} \mathrm{SiO}_{2}$. The non-adjustment of the simple linear regression for $\mathrm{SiO}_{2}$ may be because SAD does not digest quartz, as this method is intended for minerals in the clay fraction ( $\mathrm{Re}$ sende et al., 1987). The $\mathrm{SiO}_{2}$ content could be underestimated in SAD, while in the pXRF analysis, all $\mathrm{SiO}_{2}$ is detected from soil bulk composition. In the stepwise regression, the use of the sand fraction in the model as a predictor variable corrected this effect leading to better model adjustments.

For the prediction of SAD $\mathrm{Fe}_{2} \mathrm{O}_{3}$, the clay fraction was one of the independent variables inserted into the model, reinforcing the concentration of the Fe-bearing 

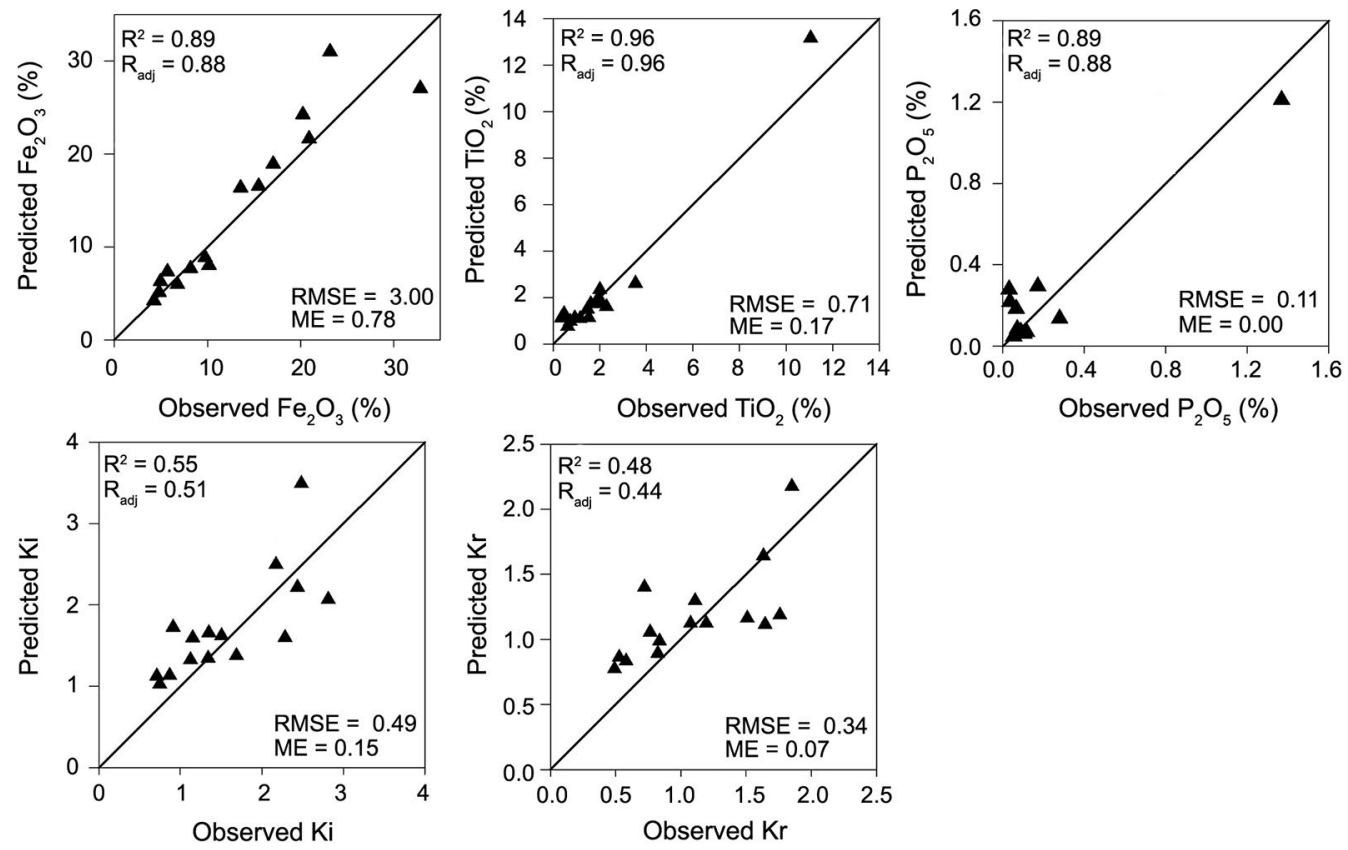

Figure 1 - Validation of simple linear regressions to predict results of sulfuric acid digestion analyses from data obtained with portable X-ray fluorescence $(p X R F)$ spectrometry. RMSE = root mean square error; $M E=$ mean error.

Table 6 - Equations, $R^{2}$, and $R_{\text {adj }}$ for stepwise multiple linear regressions to predict sulfuric acid digestion (SAD) results from data of portable X-ray fluorescence (pXRF) spectrometry, with and without incorporating soil texture data (in \%) into the models.

\begin{tabular}{|c|c|c|c|}
\hline $\begin{array}{l}\text { Elements/ } \\
\text { Weathering indices }\end{array}$ & $\mathrm{R}^{2}$ & $R_{a d j}$ & Equations \\
\hline \multicolumn{4}{|r|}{ Without soil texture } \\
\hline $\mathrm{Al}_{2} \mathrm{O}_{3}$ & 0.79 & 0.76 & $\mathrm{Al}_{2} \mathrm{O}_{3 \mathrm{SAD}}=16.854+215.02^{*} \mathrm{~V}-0.403^{*} \mathrm{SiO}_{2}-0.235^{*} \mathrm{Fe}_{2} \mathrm{O}_{3}+113.898^{*} \mathrm{Cl}+0.587^{*} \mathrm{Al}_{2} \mathrm{O}_{3}$ \\
\hline $\mathrm{SiO}_{2}$ & 0.79 & 0.71 & $\begin{array}{l}\mathrm{SiO}_{2 \text { SAD }}=29.042-438.925^{\star} \mathrm{Zr}+3.635^{*} \mathrm{TiO}_{2}+861.21^{*} \mathrm{Rb}+550.93^{*} \mathrm{Ni}-39.404^{*} \mathrm{Mn}-4.844^{*} \mathrm{~K}_{2} \mathrm{O}-0.658^{*} \mathrm{Fe}_{2} \mathrm{O}_{3}+ \\
807.238^{*} \mathrm{Cu}-69.24^{*} \mathrm{Cr}-31.562 \mathrm{P}_{2} \mathrm{O}_{5}\end{array}$ \\
\hline $\mathrm{P}_{2} \mathrm{O}_{5}$ & 0.97 & 0.96 & $\mathrm{P}_{2} \mathrm{O}_{5 \text { SAD }}=-0.231+3.074^{*} \mathrm{Zr}+15.679^{*} \mathrm{Zn}-15.344^{*} \mathrm{Rb}-0.708^{*} \mathrm{Mn}+0.00616^{*} \mathrm{Fe}_{2} \mathrm{O}_{3}+2.027^{*} \mathrm{Cl}+2.296^{*} \mathrm{P}_{2} \mathrm{O}_{5}$ \\
\hline $\mathrm{Fe}_{2} \mathrm{O}_{3}$ & 0.98 & 0.97 & $\begin{array}{l}\mathrm{Fe}_{2} \mathrm{O}_{3 \mathrm{sAA}}=5.322+292.806^{*} \mathrm{Zr}+94.698^{*} \mathrm{~V}-2.867^{\star} \mathrm{TiO}_{2}-214.855^{*} \mathrm{Rb}+760.132^{*} \mathrm{~Pb}+0.755^{*} \mathrm{Fe}_{2} \mathrm{O}_{3}-1.005^{*} \mathrm{CaO} \\
-0.343^{*} \mathrm{Al}_{2} \mathrm{O}_{3}\end{array}$ \\
\hline $\mathrm{TiO}_{2}$ & 0.99 & 0.99 & $\begin{array}{l}\mathrm{TiO}_{2 \mathrm{SAD}}=0.236+41.251^{\star} \mathrm{Zr}+185.155^{\star} \mathrm{Zn}+32.409^{*} \mathrm{~V}-104.257^{*} \mathrm{Rb}-161.695^{*} \mathrm{~Pb}+54.744^{*} \mathrm{Ni}-7.963^{*} \mathrm{Mn}+ \\
0.147^{\star} \mathrm{Fe}_{2} \mathrm{O}_{3}-112.044^{*} \mathrm{Cu}-8.487^{\star} \mathrm{Cr}+6.424^{*} \mathrm{P}_{2} \mathrm{O}_{5}-0.0677^{*} \mathrm{Al}_{2} \mathrm{O}_{3}\end{array}$ \\
\hline Ki & 0.90 & 0.86 & $\begin{array}{l}\mathrm{Ki}_{\mathrm{SAD}}=1.854-24.874^{*} \mathrm{Zr}+0.244^{*} \mathrm{TiO}_{2}+0.0252^{*} \mathrm{SiO}_{2}+40.464^{*} \mathrm{Ni}-3.821^{*} \mathrm{Mn}-0.0297^{\star} \mathrm{Fe}_{2} \mathrm{O}_{3}+44.141^{*} \mathrm{Cu}- \\
4.994^{\star} \mathrm{Cr}+0.283^{*} \mathrm{CaO}-0.0358^{*} \mathrm{Al}_{2} \mathrm{O}_{3}\end{array}$ \\
\hline $\mathrm{Kr}$ & 0.84 & 0.80 & $\mathrm{Kr}_{\mathrm{SAD}}=0.904-21.289 * \mathrm{Zr}+0.195^{*} \mathrm{TiO}_{2}+0.0223^{*} \mathrm{SiO}_{2}+18.214^{*} \mathrm{Ni}-0.0205^{*} \mathrm{Fe}_{2} \mathrm{O}_{3}-2.58^{*} \mathrm{Cr}+0.209^{*} \mathrm{CaO}$ \\
\hline \multicolumn{4}{|r|}{ With soil texture } \\
\hline $\mathrm{Al}_{2} \mathrm{O}_{3}$ & 0.94 & 0.92 & $\begin{array}{l}\mathrm{Al}_{2} \mathrm{O}_{3 \mathrm{SAD}}=-0.441-0.427^{*} \mathrm{TiO}_{2}-0.366^{*} \mathrm{SiO}_{2}-222.791 * \mathrm{~Pb}+23.88^{*} \mathrm{Mn}-255.975^{*} \mathrm{Cu}+0.726^{*} \mathrm{Al}_{2} \mathrm{O}_{3}+0.289^{*} \mathrm{Clay}+ \\
0.291^{*} \text { Silt }\end{array}$ \\
\hline $\mathrm{SiO}_{2}$ & 0.83 & 0.75 & $\begin{array}{l}\mathrm{SiO}_{2 \mathrm{SAD}}=28.549-428.159^{*} \mathrm{Zr}+2307.631^{*} \mathrm{Zn}-142.37^{*} \mathrm{~V}+4.149^{*} \mathrm{TiO}_{2}+1051.561^{*} \mathrm{Rb}+361.983^{*} \mathrm{Ni}- \\
43.614^{*} \mathrm{Mn}-7.926^{*} \mathrm{~K}_{2} \mathrm{O}-0.566^{*} \mathrm{Fe}_{2} \mathrm{O}_{3}-51.997^{*} \mathrm{Cr}-29.803^{*} \mathrm{P}_{2} \mathrm{O}_{5}-0.118^{*} \mathrm{Sand}\end{array}$ \\
\hline $\mathrm{P}_{2} \mathrm{O}_{5}$ & 0.97 & 0.97 & $\begin{array}{l}\mathrm{P}_{2} \mathrm{O}_{5 \mathrm{SAD}}=-0.123+2.466 * \mathrm{Zr}-0.00633^{*} \mathrm{SiO}_{2}-6.898 * \mathrm{Rb}-0.77^{*} \mathrm{Mn}+11.87^{*} \mathrm{Cu}+1.755^{*} \mathrm{Cl}+2.15^{*} \mathrm{P}_{2} \mathrm{O}_{5}+ \\
0.00291{ }^{*} \mathrm{Silt}+0.00346{ }^{*} \text { Sand }\end{array}$ \\
\hline $\mathrm{Fe}_{2} \mathrm{O}_{3}$ & 0.98 & 0.97 & $\begin{array}{l}\mathrm{Fe}_{2} \mathrm{O}_{3 \mathrm{SAD}}=9.247+283.057^{\star} \mathrm{Zr}+125.875^{*} \mathrm{~V}-2.832^{*} \mathrm{TiO}_{2}+661.863^{*} \mathrm{~Pb}-1.617^{*} \mathrm{~K}_{2} \mathrm{O}+0.772^{*} \mathrm{Fe}_{2} \mathrm{O}_{3}-1.245^{*} \mathrm{CaO} \\
-0.333^{\star} \mathrm{Al}_{2} \mathrm{O}_{3}-0.0774^{*} \mathrm{Clay}\end{array}$ \\
\hline $\mathrm{TiO}_{2}$ & 0.99 & 0.99 & $\begin{array}{l}\mathrm{TiO}_{2 \mathrm{SAO}}=1.184+35.331^{*} \mathrm{Zr}+39.467^{*} \mathrm{~V}-0.0338^{*} \mathrm{SiO}_{2}-110.469^{*} \mathrm{Rb}-131.694^{*} \mathrm{~Pb}+69.278^{*} \mathrm{Ni}-8.447^{*} \mathrm{Mn}+ \\
0.51^{*} \mathrm{~K}_{2} \mathrm{O}+0.1^{*} \mathrm{Fe}_{2} \mathrm{O}_{3}-9.786^{*} \mathrm{Cr}+5.27^{*} \mathrm{P}_{2} \mathrm{O}_{5}-0.0694^{*} \mathrm{Al}_{2} \mathrm{O}_{3}+0.0181^{*} \mathrm{Sand}\end{array}$ \\
\hline Ki & 0.90 & 0.86 & $\begin{array}{l}\mathrm{Ki}_{3 S A D}=3.036-31.479^{*} \mathrm{Zr}+0.308^{*} \mathrm{TiO}_{2}+33.954^{*} \mathrm{Rb}+32.739^{*} \mathrm{Ni}-3.586^{*} \mathrm{Mn}-0.0501^{\star} \mathrm{Fe}_{2} \mathrm{O}_{3}+62.353^{*} \mathrm{Cu}- \\
4.229^{*} \mathrm{Cr}+0.26^{*} \mathrm{CaO}-0.0241^{*} \mathrm{Al}_{2} \mathrm{O}_{3}-0.0114^{*} \mathrm{Clay}\end{array}$ \\
\hline $\mathrm{Kr}$ & 0.84 & 0.80 & $\mathrm{Kr}_{\mathrm{SAD}}=0.901-20.877^{*} \mathrm{Zr}+0.188^{*} \mathrm{TiO}_{2}+0.0223^{*} \mathrm{SiO}_{2}+18.648^{*} \mathrm{Ni}-0.0202^{*} \mathrm{Fe}_{2} \mathrm{O}_{3}-2.633^{*} \mathrm{Cr}+0.21{ }^{*} \mathrm{CaO}$ \\
\hline
\end{tabular}


minerals in the smallest particle fractions in soils as the weathering processes advance, mainly as hematite and goethite (Kämpf et al., 2012). The sand fraction was included as predictor variable into the SAD $\mathrm{TiO}_{2}$ model, whereas both sand and silt fractions were present in the model for the SAD $\mathrm{P}_{2} \mathrm{O}_{5}$ prediction. This result indicates the presence of minerals containing $\mathrm{P}$ and $\mathrm{Ti}$ in the sand and silt fractions in the soils studied. The sand and silt fractions of soils developed from basalt, gabbro, tuffite, and amphibolite may present considerable amounts of minerals such as anatase, rutile, and titanomagnetite, which present $\mathrm{Ti}$ in their composition (Fabris et al., 1997; Fabris et al., 1998).

The Ki and $\mathrm{Kr}$ indices were also submitted to stepwise multiple linear regressions, yielding $\mathrm{R}^{2}$ values of 0.90 and 0.84 , respectively. Models with and without soil texture data had similar $\mathrm{R}^{2}$ values. Most predictor variables were the same in models with and without incorporation of soil texture data, except for the prediction of Ki values. In this last case, by incorporating soil texture data into the model, the clay content was added to the model while $\mathrm{Si}$ was replaced by $\mathrm{Rb}$.

The validation indices for prediction of SAD values and weathering indices from the formerly presented equations are shown in Figure 2. Except for $\mathrm{Kr}_{1} \mathrm{Fe}_{2} \mathrm{O}_{3}$, and $\mathrm{SiO}_{2}$, validation indices were always better when incorporating soil texture into the models. $\mathrm{P}_{2} \mathrm{O}_{5}, \mathrm{TiO}_{2}, \mathrm{Ki}$, and $\mathrm{Kr}$ presented RMSE and ME values close to zero for validation of models with and without incorporating soil texture data, which is in agreement with the low range of their values. $\mathrm{R}^{2}$ and $\mathrm{R}^{2}$ adj for $\mathrm{Fe}_{2} \mathrm{O}_{3}$ validation without incorporating texture data were the same as those
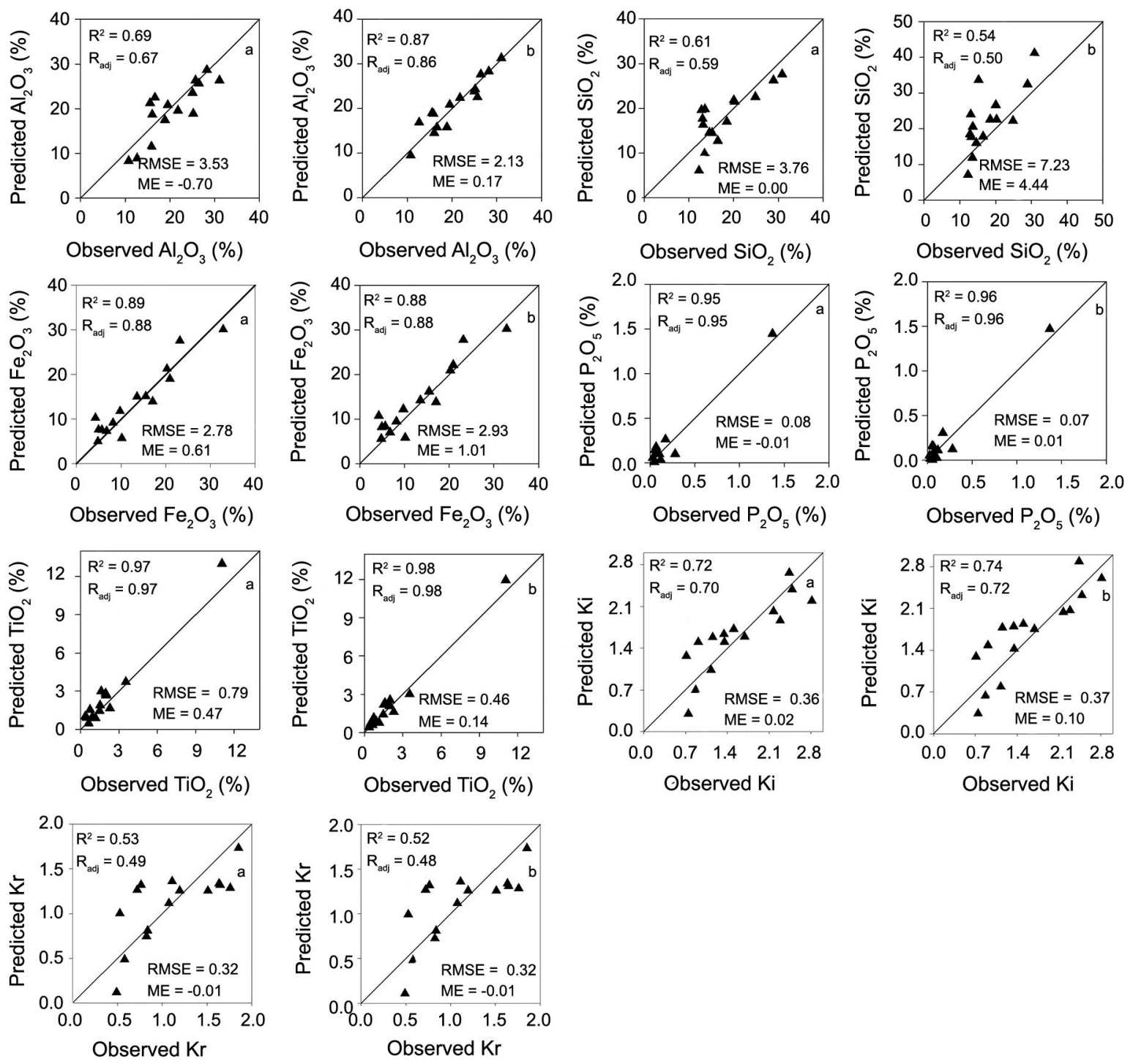

Figure 2 - Validation of stepwise multiple linear regressions to predict results of sulfuric acid digestion analyses from portable X-ray fluorescence (pXRF) spectrometry data without (a) and with (b) soil texture data. RMSE = root mean square error; ME = mean error. 
found with simple linear regressions, but RMSE and ME values were lower with the stepwise regression. These values were slightly better than those that incorporated texture data as predictors. $\mathrm{P}_{2} \mathrm{O}_{5}$ and $\mathrm{TiO}_{2}$ had a similar trend, with validation of models incorporating texture presenting better results. Predictions of these elements were also improved in comparison to simple regressions.

A considerable improvement in the modeling and validations was achieved for $\mathrm{Al}_{2} \mathrm{O}_{3}$ and $\mathrm{SiO}_{2}$ values, whose models reached $\mathrm{R}^{2}$ and $\mathrm{R}_{\text {adj }}^{2}$ that were much higher than those obtained with simple regressions. $\mathrm{Al}_{2} \mathrm{O}_{3}$ validation indicated that texture improved validation indices and the opposite trend was found for $\mathrm{SiO}_{2}$. $\mathrm{Ki}$ and $\mathrm{Kr}$ also improved in modeling and prediction quality compared to simple regression, although their validation indices were lower than those obtained for the predictions of SAD elemental contents.

In general, when using multiple regressions, texture data and pXRF elemental data other than $\mathrm{Fe}, \mathrm{Ti}$, $\mathrm{Al}, \mathrm{Si}$, and $\mathrm{P}$ were fundamental to improve prediction of SAD results, although predictions of $\mathrm{SAD} \mathrm{Fe}_{2} \mathrm{O}_{3}, \mathrm{TiO}_{2}$, and $\mathrm{P}_{2} \mathrm{O}_{5}$ also provided adequate results using simple linear regressions. This shows that besides soil texture, the mineralogical composition of different particle size fractions also influences the results and can be accessed by pXRF. Attention should be drawn to the fact that some of the elements used in the equations presented low recovery values, which is important since they tend to be present in small concentrations in the soils.

\section{Random forest modeling and predictions}

Random forest models for most SAD elemental contents as well as for $\mathrm{Ki}$ and $\mathrm{Kr}$ presented high percentage of variance explained and small errors (Table 7), indicating good adjustments of the models. Little variation occurred by adding information on soil texture into the models, except for $\mathrm{Al}_{2} \mathrm{O}_{3}$, which showed an improvement of $13 \%$ of variance explained in the presence of such data.

The most important variables for predicting SAD $\mathrm{SiO}_{2}, \mathrm{Fe}_{2} \mathrm{O}_{3}, \mathrm{Ki}$ and $\mathrm{Kr}$ were these elemental contents/ weathering indices obtained from pXRF even in the presence of sand, silt, and clay data (Table 8). For the $\mathrm{SAD} \mathrm{Al}_{2} \mathrm{O}_{3}$ model, the clay content was the most important variable, followed by pXRF $\mathrm{Rb}$ and $\mathrm{Al}_{2} \mathrm{O}_{3}$ contents.

Table 7 - Modeling results to predict sulfuric acid digestion results from portable X-ray fluorescence (pXRF) spectrometry by random forest algorithm, with and without incorporating soil texture data into the models.

\begin{tabular}{|c|c|c|c|c|c|c|c|}
\hline Paramenter $^{1}$ & $\mathrm{SiO}_{2}$ & $\mathrm{Al}_{2} \mathrm{O}_{3}$ & $\mathrm{Fe}_{2} \mathrm{O}_{3}$ & $\mathrm{TiO}_{2}$ & $\mathrm{P}_{2} \mathrm{O}_{5}$ & Ki & $\mathrm{Kr}$ \\
\hline & \multicolumn{7}{|c|}{ Without soil texture } \\
\hline VarEx & 25.72 & 38.63 & 47.59 & 67.88 & 40.69 & 65.08 & 64.81 \\
\hline \multirow[t]{2}{*}{ MSE } & 24.63 & 30.46 & 86.33 & 2.73 & 0.06 & 0.20 & 0.08 \\
\hline & \multicolumn{7}{|c|}{ With soil texture } \\
\hline VarEx & 24.33 & 51.20 & 49.04 & 66.47 & 40.72 & 60.2 & 63.14 \\
\hline MSE & 25.10 & 24.22 & 83.93 & 2.85 & 0.06 & 0.23 & 0.08 \\
\hline
\end{tabular}

Table 8 - Importance of the variables (Imp) for random forest models using only pXRF data or pXRF together with texture data to predict results from sulfuric acid digestion analyses.

\begin{tabular}{|c|c|c|c|c|c|c|c|c|c|c|c|c|c|c|}
\hline \multirow{3}{*}{ Imp } & \multicolumn{7}{|c|}{ Predicted variable } & \multicolumn{7}{|c|}{ Predicted variable } \\
\hline & $\mathrm{SiO}_{2}$ & $\mathrm{Al}_{2} \mathrm{O}_{3}$ & $\mathrm{Fe}_{2} \mathrm{O}_{3}$ & $\mathrm{TiO}_{2}$ & $\mathrm{P}_{2} \mathrm{O}_{5}$ & Ki & $\mathrm{Kr}$ & $\mathrm{SiO}_{2}$ & $\mathrm{Al}_{2} \mathrm{O}_{3}$ & $\mathrm{Fe}_{2} \mathrm{O}_{3}$ & $\mathrm{TiO}_{2}$ & $\mathrm{P}_{2} \mathrm{O}_{5}$ & Ki & $\mathrm{Kr}$ \\
\hline & \multicolumn{7}{|c|}{ Only pXRF data } & \multicolumn{7}{|c|}{ pXRF + texture data } \\
\hline 1 & $\mathrm{SiO}_{2}$ & $\mathrm{Rb}$ & $\mathrm{Fe}_{2} \mathrm{O}_{3}$ & $\mathrm{~V}$ & $\mathrm{SiO}_{2}$ & Ki_pXRF & Kr_pXRF & $\mathrm{SiO}_{2}$ & Clay & $\mathrm{Fe}_{2} \mathrm{O}_{3}$ & $\mathrm{~V}$ & $\mathrm{Zr}$ & Ki_pXRF & Kr_pXRF \\
\hline 2 & $\mathrm{Cr}^{2}$ & $\mathrm{Al}_{2} \mathrm{O}_{3}$ & $\mathrm{~Pb}$ & $\mathrm{TiO}_{2}$ & $\mathrm{TiO}_{2}$ & $\mathrm{SiO}_{2}$ & $\mathrm{SiO}_{2}$ & $\mathrm{Zn}$ & $\mathrm{Rb}$ & $\mathrm{Pb}$ & $\mathrm{TiO}_{2}$ & $\mathrm{TiO}_{2}$ & $\mathrm{SiO}_{2}$ & $\mathrm{SiO}_{2}$ \\
\hline 3 & $\mathrm{Zn}$ & $\mathrm{K}_{2} \mathrm{O}$ & $\mathrm{TiO}_{2}$ & $\mathrm{Zr}$ & $\mathrm{Mn}^{2}$ & $\mathrm{Al}_{2} \mathrm{O}_{3}$ & $\mathrm{~K}_{2} \mathrm{O}$ & $\mathrm{Cr}$ & $\mathrm{Al}_{2} \mathrm{O}_{3}$ & $\mathrm{TiO}_{2}$ & $\mathrm{Fe}_{2} \mathrm{O}_{3}$ & $\mathrm{~Pb}$ & Silt & $\mathrm{K}_{2} \mathrm{O}$ \\
\hline 4 & $\mathrm{Ni}$ & $\mathrm{SiO}_{2}$ & $\mathrm{Cu}$ & $\mathrm{Fe}_{2} \mathrm{O}_{3}$ & $\mathrm{Cu}$ & $\mathrm{P}_{2} \mathrm{O}_{5}$ & $\mathrm{Cr}$ & Silt & $\mathrm{K}_{2} \mathrm{O}$ & V & $\mathrm{Zr}$ & $\mathrm{SiO}_{2}$ & $\mathrm{P}_{2} \mathrm{O}_{5}$ & $\mathrm{Zn}$ \\
\hline 5 & $\mathrm{Cu}$ & $\mathrm{P}_{2} \mathrm{O}_{5}$ & V & $\mathrm{Cr}$ & $\mathrm{Zr}$ & $\mathrm{Zn}$ & $\mathrm{Fe}_{2} \mathrm{O}_{3}$ & $\mathrm{Cu}$ & $\mathrm{P}_{2} \mathrm{O}_{5}$ & $\mathrm{Cu}$ & $\mathrm{Cu}$ & $\mathrm{Mn}$ & $\mathrm{Zn}$ & $\mathrm{Pb}$ \\
\hline 6 & $\mathrm{~K}_{2} \mathrm{O}$ & V & $\mathrm{SiO}_{2}$ & $\mathrm{Mn}$ & $\mathrm{Cl}$ & $\mathrm{K}_{2} \mathrm{O}$ & $\mathrm{Zn}$ & $\mathrm{K}_{2} \mathrm{O}$ & $\mathrm{SiO}_{2}$ & $\mathrm{SiO}_{2}$ & $\mathrm{Mn}$ & $\mathrm{P}_{2} \mathrm{O}_{5}$ & $\mathrm{~K}_{2} \mathrm{O}$ & $\mathrm{CaO}$ \\
\hline 7 & $\mathrm{~Pb}$ & $\mathrm{CaO}$ & $\mathrm{Ni}^{2}$ & $\mathrm{Cu}$ & $\mathrm{P}_{2} \mathrm{O}_{5}$ & $\mathrm{CaO}$ & $\mathrm{CaO}$ & $\mathrm{Fe}_{2} \mathrm{O}_{3}$ & Sand & $\mathrm{Zr}$ & $\mathrm{Cl}$ & $\mathrm{Cu}$ & $\mathrm{Al}_{2} \mathrm{O}_{3}$ & $\mathrm{Cr}$ \\
\hline 8 & $\mathrm{Fe}_{2} \mathrm{O}_{3}$ & $\mathrm{~Pb}$ & $\mathrm{Zr}$ & $\mathrm{Ni}$ & $\mathrm{Ni}$ & $\mathrm{Cu}$ & $\mathrm{Pb}$ & Sand & $\mathrm{Cr}$ & $\mathrm{Mn}$ & $\mathrm{Cr}$ & $\mathrm{Cl}$ & $\mathrm{CaO}$ & Silt \\
\hline 9 & $\mathrm{Cl}$ & $\mathrm{Mn}$ & $\mathrm{Al}_{2} \mathrm{O}_{3}$ & $\mathrm{Cl}$ & $\mathrm{Fe}_{2} \mathrm{O}_{3}$ & $\mathrm{~Pb}$ & $\mathrm{Al}_{2} \mathrm{O}_{3}$ & $\mathrm{Ni}$ & V & $\mathrm{Zn}$ & $\mathrm{P}_{2} \mathrm{O}_{5}$ & $\mathrm{Ni}$ & Clay & $\mathrm{Fe}_{2} \mathrm{O}_{3}$ \\
\hline 10 & $\mathrm{CaO}$ & $\mathrm{Cr}$ & $\mathrm{Mn}$ & $\mathrm{P}_{2} \mathrm{O}_{5}$ & $\mathrm{~Pb}$ & $\mathrm{Fe}_{2} \mathrm{O}_{3}$ & $\mathrm{Cu}$ & $\mathrm{Cl}$ & $\mathrm{CaO}$ & $\mathrm{Al}_{2} \mathrm{O}_{3}$ & $\mathrm{Ni}$ & Sand & $\mathrm{Pb}$ & $\mathrm{Al}_{2} \mathrm{O}_{3}$ \\
\hline 11 & $\mathrm{Mn}$ & $\mathrm{Fe}_{2} \mathrm{O}_{3}$ & $\mathrm{Zn}$ & $\mathrm{SiO}_{2}$ & $\mathrm{CaO}$ & $\mathrm{Ni}$ & $\mathrm{Rb}$ & $\mathrm{CaO}$ & $\mathrm{Fe}_{2} \mathrm{O}_{3}$ & $\mathrm{Ni}$ & $\mathrm{CaO}$ & $\mathrm{Zn}$ & $\mathrm{Cr}$ & Clay \\
\hline 12 & V & $\mathrm{Zr}$ & $\mathrm{CaO}$ & $\mathrm{K}_{2} \mathrm{O}$ & $\mathrm{Al}_{2} \mathrm{O}_{3}$ & $\mathrm{Cr}$ & $\mathrm{Ni}$ & $\mathrm{Al}_{2} \mathrm{O}_{3}$ & Silt & Sand & $\mathrm{SiO}_{2}$ & $\mathrm{Fe}_{2} \mathrm{O}_{3}$ & $\mathrm{Ni}$ & $\mathrm{Rb}$ \\
\hline 13 & $\mathrm{Zr}$ & $\mathrm{Cl}$ & $\mathrm{Cr}$ & $\mathrm{Zn}$ & $\mathrm{Zn}$ & $\mathrm{Rb}$ & $\mathrm{P}_{2} \mathrm{O}_{5}$ & $\mathrm{TiO}_{2}$ & $\mathrm{~Pb}$ & $\mathrm{Cl}$ & $\mathrm{Zn}$ & $\mathrm{CaO}$ & Sand & $\mathrm{Cu}$ \\
\hline 14 & $\mathrm{Al}_{2} \mathrm{O}_{3}$ & $\mathrm{Zn}$ & $\mathrm{Rb}$ & $\mathrm{Al}_{2} \mathrm{O}_{3}$ & $\mathrm{~K}_{2} \mathrm{O}$ & $\mathrm{Mn}$ & $\mathrm{TiO}_{2}$ & $\mathrm{~Pb}$ & $\mathrm{Mn}$ & $\mathrm{CaO}$ & $\mathrm{Al}_{2} \mathrm{O}_{3}$ & $\mathrm{Rb}$ & $\mathrm{Cu}$ & $\mathrm{TiO}_{2}$ \\
\hline 15 & $\mathrm{TiO}_{2}$ & $\mathrm{Ni}$ & $\mathrm{Cl}$ & $\mathrm{CaO}$ & $\mathrm{Rb}$ & $\mathrm{Cl}$ & V & $\mathrm{Mn}$ & $\mathrm{Cu}$ & $\mathrm{K}_{2} \mathrm{O}$ & $\mathrm{K}_{2} \mathrm{O}$ & Clay & $\mathrm{Cl}$ & $\mathrm{Ni}$ \\
\hline 16 & $\mathrm{P}_{2} \mathrm{O}_{5}$ & $\mathrm{TiO}_{2}$ & $\mathrm{~K}_{2} \mathrm{O}$ & $\mathrm{Pb}$ & $\mathrm{Cr}$ & $\mathrm{TiO}_{2}$ & $\mathrm{Cl}$ & $\mathrm{P}_{2} \mathrm{O}_{5}$ & $\mathrm{Cl}$ & Silt & $\mathrm{Pb}$ & $\mathrm{Al}_{2} \mathrm{O}_{3}$ & $\mathrm{Mn}$ & $\mathrm{P}_{2} \mathrm{O}_{5}$ \\
\hline 17 & $\mathrm{Rb}$ & $\mathrm{Cu}^{2}$ & $\mathrm{P}_{2} \mathrm{O}_{5}$ & $\mathrm{Rb}$ & V & $v^{2}$ & $\mathrm{Zr}$ & $\mathrm{Rb}$ & $\mathrm{Ni}$ & $\mathrm{Rb}$ & Clay & $\mathrm{Cr}$ & $\mathrm{TiO}_{2}$ & V \\
\hline 18 & - & - & - & - & - & $\mathrm{Zr}$ & $\mathrm{Mn}$ & V & $\mathrm{TiO}_{2}$ & $\mathrm{Cr}$ & Silt & $\mathrm{K}_{2} \mathrm{O}$ & $\mathrm{Fe}_{2} \mathrm{O}_{3}$ & $\mathrm{Cl}$ \\
\hline 19 & - & - & - & - & - & - & - & $\mathrm{Zr}$ & $\mathrm{Zr}$ & Clay & Sand & V & $\mathrm{Zr}$ & Sand \\
\hline 20 & - & - & - & - & - & - & - & Clay & $\mathrm{Zn}$ & $\mathrm{P}_{2} \mathrm{O}_{5}$ & $\mathrm{Rb}$ & Silt & $\mathrm{Rb}$ & $\mathrm{Zr}$ \\
\hline 21 & - & - & - & - & - & - & - & - & - & - & - & - & V & $\mathrm{Mn}$ \\
\hline
\end{tabular}


In the model without soil texture variables, $\mathrm{Rb}$ was the most important, followed by $\mathrm{Al}_{2} \mathrm{O}_{3}$. This fact demonstrates the importance of variables provided by $\mathrm{pXRF}$ for these predictions. Zhu et al. (2011) used pXRF data for predicting sand and clay contents in soils from Lousiana and New Mexico (USA) and found a correlation of 0.91 between $\mathrm{Rb}$ and clay contents. These findings may indicate a similar trend also for Brazilian soils, although these authors are aware of differences between those soils and the ones in our study.

For $\mathrm{SAD} \mathrm{SiO}{ }_{2}$ prediction, silt and sand were defined as the $4^{\text {th }}$ and $8^{\text {th }}$ most important variables, and clay was the least important. In both models for SAD $\mathrm{TiO}_{2}, \mathrm{pXRF}$ $\mathrm{V}$ was the most important variable, followed by pXRF $\mathrm{TiO}_{2}$. As expected, the indices $\mathrm{Ki}$ and $\mathrm{Kr}$ calculated using $\mathrm{pXRF} \mathrm{SiO}_{2}, \mathrm{Al}_{2} \mathrm{O}_{3}$, and $\mathrm{Fe}_{2} \mathrm{O}_{3}$ results were the most important variables to predict SAD $\mathrm{Ki}$ and $\mathrm{Kr}$, followed by pXRF $\mathrm{SiO}_{2}$, since the latter element is taken into account in the formulae used to calculate those indices.

The validation of the random forest models is presented in Figure 3. The validation results, in general, were very similar with and without incorporation of soil texture data into the models. Thus, for random forest algorithms, soil texture data did not improve the predictions of $\mathrm{SAD}$ results and $\mathrm{Ki}$ and $\mathrm{Kr}$ values. However, random forest provided better results for $\mathrm{SAD} \mathrm{Al}_{2} \mathrm{O}_{3}$ with texture data, and $\mathrm{SAD} \mathrm{Fe}_{2} \mathrm{O}_{3}$ and $\mathrm{Kr}$ with and without this attribute data in comparison to stepwise regression. It demonstrates that, without information on soil texture, random forest algorithms can be used to deliver better predictions of $\mathrm{SAD} \mathrm{Fe}_{2} \mathrm{O}_{3}$, and $\mathrm{Kr}$ than stepwise multiple linear regressions.

\section{Influence of soil texture on the prediction of weathering indexes}

The prediction of elemental contents (expressed on the oxide basis) and weathering indices from the pXRF analysis was substantially improved when texture was used, especially in the multiple regression analysis for $\mathrm{Al}_{2} \mathrm{O}_{3}$ and $\mathrm{SiO}_{2}$. The reasons for this occurrence are, first, due to the nature of the SAD and pXRF analyses: while the SAD is efficient in the dissolution of minerals of the clay fraction, the pXRF analysis provides results of the total chemical composition of the sample. Thus,
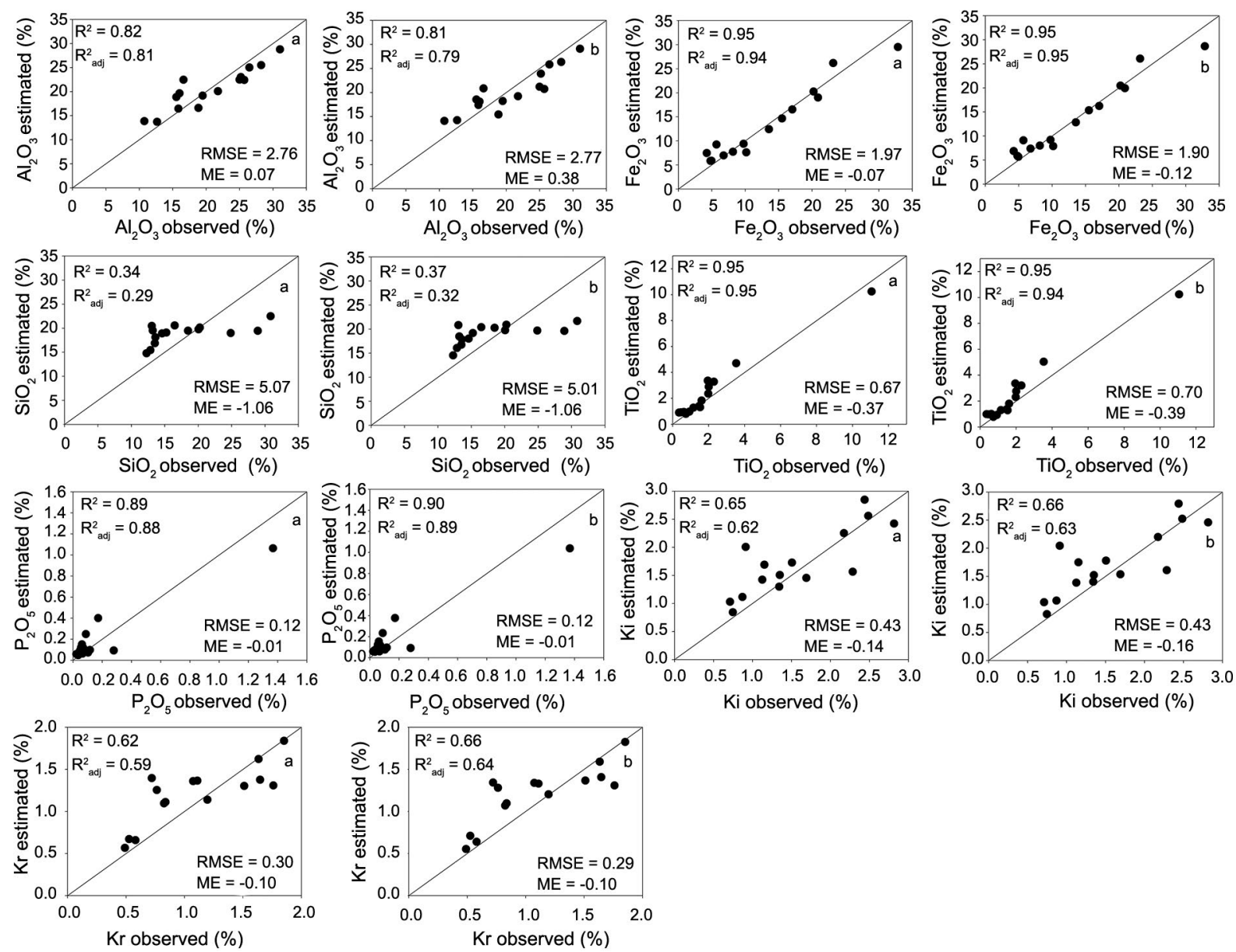

Figure 3 - Validation of random forest models to predict results of sulfuric acid digestion analyses from portable X-ray fluorescence data without (a) and with (b) soil texture data. RMSE = root mean square error; ME = mean error. 
such $\mathrm{pXRF}$ results may differ from those obtained from other analyses, including $\mathrm{SAD}$, which explains the reason why the incorporation of soil texture into the models in addition to the contents of elements in the minerals was decisive for the improvement of the prediction models. Second, mineralogy of Brazilian soils is mostly dominated by kaolinite, $\mathrm{Fe}$ and $\mathrm{Al}$ oxides (hematite, goethite, and gibbsite) in the clay fraction and quartz in association with smaller contents of muscovite in the sand fraction (Melo et al., 2001; Inda et al., 2010; Kämpf et al., 2012; Silva et al., 2012; Carvalho Filho et al., 2015). The dominance of either sand or clay fraction in most Brazilian soils reflects the soil parent material. The silt content is much lower due to the high weathering degree of these soils (Tables 3 and 4) and represents the maximum instability fraction. Thus, the sand and clay contents as well as the mineralogical composition of these particle size fractions influenced primarily the predictions of $\mathrm{SAD} \mathrm{Al}_{2} \mathrm{O}_{3}$ and $\mathrm{SiO}_{2}$ contents. Thus, considering the high validation indices for all the SAD results and weathering indices, pXRF could be adopted as an alternative method to provide such soil data. The creation of better models to predict SAD results is encouraged, mainly through incorporation of more soil data.

\section{Conclusions}

Accurate predictions of $\mathrm{SAD} \mathrm{Al}_{2} \mathrm{O}_{3}, \mathrm{Fe}_{2} \mathrm{O}_{3}, \mathrm{SiO}_{2}$ $\mathrm{P}_{2} \mathrm{O}_{5}$, and $\mathrm{TiO}_{2}$ results as well as $\mathrm{Ki}$ and $\mathrm{Kr}$ weathering indices can be obtained using pXRF data with and without incorporation of soil texture data into the models, through simple linear regressions, stepwise multiple linear regressions, and random forest algorithm. The clay and sand contents were crucial to improve the models to predict $\mathrm{SAD} \mathrm{Al}_{2} \mathrm{O}_{3}$ and $\mathrm{SiO}_{2}$, respectively. These findings demonstrate that it is possible to use $\mathrm{pXRF}$ to reduce costs, time, and the amount of chemical waste produced by the SAD analyses. In addition, these results contribute to speeding up not only soil chemical characterization, but also the assessment of information on soil weathering degree, geochemical balance of nutrients, parent material homogeneity, reserve of nutrients for perennial crops, mineralogy of the clay fraction, among others. Finally, the association of new tools and robust algorithms enhance soil characterization for varying purposes, while providing a fast, cost-effective, and "green chemistry" alternative for the SAD analyses.

\section{Authors' Contributions}

Conceptualization: Silva, S.H.G.; Silva, E.A.; Poggere, G.C.; Guilherme, L.R.G.; Curi, N. Data acquisition: Silva, S.H.G.; Silva, E.A.; Poggere, G.C.; Pádua Junior, A.L.; Gonçalves, M.G.M. Data analysis: Silva, S.H.G.; Silva, E.A.; Poggere, G.C.; Pádua Junior, A.L.; Gonçalves, M.G.M. Design of Methodology: Silva, S.H.G.; Silva, E.A.; Poggere, G.C.; Curi, N. Writing and editing: Silva, S.H.G.; Silva, E.A.; Guilherme, L.R.G.; Curi, N.

\section{References}

Aldabaa, A.A.A.; Weindorf, D.C.; Chakraborty, S.; Sharma, A.; Li, B. 2015. Combination of proximal and remote sensing methods for rapid soil salinity quantification. Geoderma 239: 34-46.

Baver, L.D.; Gardner, W.H.; Gardner, W.R. 1972. Soil Physics. John Wiley, New York, NY, USA.

Breiman, L. 2001. Random forests. Machine Learning 45: 5-32.

Brinatti, A.M.; Mascarenhas, Y.P.; Pereira, V.P.; Partiti, C.S.D.; Macedo, A. 2010. Mineralogical characterization of a highlyweathered soil by the Rietveld method. Scientia Agricola 67: 454-464.

Carvalho Filho, A.; Inda, A.V.; Fink, J.R.; Curi, N. 2015. Iron oxides in soils of different lithological origins in Ferriferous quadrilateral (Minas Gerais, Brazil). Applied Clay Science 118: 1-7.

Chagas, C.S.; Carvalho Junior, W.; Bhering, S.B.; Calderano Filho, B. 2016. Spatial prediction of soil surface texture in a semiarid region using random forest and multiple linear regressions. Catena 139: 232-240.

Chakraborty, S.; Man, T.; Paulette, L.; Deb, S.; Li, B.; Weindorf, D.C.; Frazier, M. 2017. Rapid assessment of smelter/mining soil contamination via portable X-ray fluorescence spectrometry and indicator kriging. Geoderma 306: 108-119.

Curi, N.; Franzmeier, D.P. 1987. Effect of parent rocks on chemical and mineralogical properties of some Oxisols in Brazil. Soil Science Society of American Journal 51: 153158.

Curi, N.; Kämpf, N. 2012. Soil characterization = Caracterização do solo. p. 147-170. In: Ker, J.C.; Curi, N.; Schaefer, C.E.G.R.; Vidal-Torrado, P., eds. Pedology: fundamentals = Pedologia: fundamentos. SBCS, Viçosa, MG, Brazil (in Portuguese).

Duda, B.M.; Weindorf, D.C.; Chakraborty, S.; Li, B.; Man, T.; Paulette, L.; Deb, S. 2017. Soil characterization across catenas via advanced proximal sensors. Geoderma 298: 78-91.

Empresa Brasileira de Pesquisa Agropecuária [Embrapa]. 1997. Manual of soil analysis methods = Manual de métodos de análises de solos. Embrapa Solos, Rio de Janeiro, RJ, Brazil (in Portuguese).

Fabris, J.D.; Jesus Filho, M.F.; Coey, J.M.D.; Mussel, W.N.; Goulart, A.T. 1997. Iron-rich spinels from Brazilian soils. Hyperfine Interactions 110: 23-32.

Fabris, J.D.; Coey, J.M.D.; Mussel, W.N. 1998. Magnetic soils from mafic lithodomains in Brazil. Hyperfine Interactions 114: 249-258.

Forkuor, G.; Hounkpatin, O.K.L.; Welp, G.; Thiel, M. 2017. High resolution mapping of soil properties using remote sensing variables in south-western Burkina Faso: a comparison of machine learning and multiple linear regression models. Plos One 12: e0170478.

Gee, G.W.; Bauder, J.W. 1986. Particle-size analysis. p. 383-412. In: Klute, A., ed. Methods of soil analysis. American Society of Agronomy, Madison, WI, USA.

Inda, A.V.; Torrent, J.; Barrón, V.; Bayer, C. 2010. Aluminum hydroxy-interlayered minerals and chemical properties of a subtropical brazilian Oxisol under no-tillage and conventional tillage. Revista Brasileira de Ciência do Solo 34: 33-41. 
Kämpf, N.; Marques, J.J.; Curi, N. 2012. Mineralogy of brazilian soils $=$ Mineralogia de Solos Brasileiros. p. 81-146. In: Pedology fundamentals $=$ Pedologia fundamentos. SBCS, Viçosa, MG, Brazil (in Portuguese).

Liaw, A.; Wiener, M. 2002. Classification and regression by random forest. R News 2: 18-22.

Liaw, A.; Wiener, M. 2015. Package "randomForest". R Development Core Team 2: 1-29.

McGladdery, C.; Weindorf, D.C.; Chakraborty, S.; Li, B.; Paulette, L.; Podar, D.; Pearson, D.; Kusi, N.Y.O.; Duda, B. 2018. Elemental assessment of vegetation via portable X-ray fluorescence (PXRF) spectrometry. Journal of Environmental Management 210: 210-225.

Melo, V.F.; Singh, B.; Schaefer, C.E.G.R.; Novais, R.F.; Fontes, M.P.F. 2001. Chemical and mineralogical properties of kaolinite-rich brazilian soils. Soil Science Society America Journal 65: 1324-1333.

Peinado, F.M.; Ruano, S.M.; González, M.G.B.; Molina, C.E. 2010. A rapid field procedure for screening trace elements in polluted soil using portable X-ray fluorescence (PXRF). Geoderma 159: 76-82.

Resende, M.; Bahia Filho, A.F.C.; Braga, J.M. 1987. Clay mineralogy of Latossols estimated by chemical allocation of total oxides contents by $\mathrm{H}_{2} \mathrm{SO}_{4}$ digestion. Revista Brasileira de Ciência do Solo 23: 17-23 (in Portuguese, with abstract in English).

Ribeiro, B.T.; Silva, S.H.G.; Silva, E.A.; Guilherme, L.R.G. 2017. Portable X-ray fluorescence (pXRF) applications in tropical Soil Science. Ciência e Agrotecnologia 41: 245-254.

Ribeiro, B.T.; Weindorf, D.C.; Silva, B.M.; Tassinari, D.; Amarante, L.C.; Curi, N.; Guilherme, L.R.G. 2018. The influence of soil moisture on oxide determination in tropical soils via portable X-ray fluorescence. Soil Science Society of America Journal 82: 632-644.

Rouillon, M.; Taylor, M.P. 2016. Can field portable X-ray fluorescence ( $\mathrm{pXRF}$ ) produce high quality data for application in environmental contamination research? Environmental Pollution 214: 255-264.

Rourke, S.M.O.; Stockmann, U.; Holden, N.M.; Mcbratney, A.B.; Minasny, B. 2016. An assessment of model averaging to improve predictive power of portable vis-NIR and XRF for the determination of agronomic soil properties. Geoderma 279: 3144.

Santana, M.L.T.; Ribeiro, B.T.; Silva, S.H.G.; Poggere, G.C.; Guilherme, L.R.G.; Curi, N. 2018. Conditions affecting oxide quantification in unknown tropical soils via handheld X-ray fluorescence spectrometer. Soil Research 56: 648-655.

Santos, W.J.R.; Curi, N.; Silva, S.H.G.; Fonseca, S.; Silva, E.; Marques, J.J. 2014. Detailed soil survey of an experimental watershed representative of the brazilian Coastal Plains and its practical application. Ciência e Agrotecnologia 38: 50-60.
Schaefer, C.E.G.R.; Fabris, J.D.; Ker, J.C. 2008. Minerals in the clay fraction of brazilian Latosols (Oxisols): a review. Clay Minerals 43: 137-154.

Schaetzl, R.J.; Anderson, S. 2005. Soil: Genesis and Geomorphology. Cambridge University Press, New York, NY, USA.

Sharma, A.; Weindorf, D.C.; Man, T.; Aldabaa, A.A.A.; Chakraborty, S. 2014. Characterizing soils via portable X-ray fluorescence spectrometer. 3. Soil reaction $(\mathrm{pH})$. Geoderma 232-234: 141-147.

Sharma, A.; Weindorf, D.C.; Wang, D.; Chakraborty, S. 2015. Characterizing soils via portable X-ray fluorescence spectrometer. 4. Cation exchange capacity (CEC). Geoderma 239: $130-134$

Silva, E.A.; Gomes, J.B.V.; Filho, J.C.A.; Vidal-Torrado, P.; Cooper, M.; Curi, N. 2012. Morphology, mineralogy and micromorphology of soils associated to summit depressions of the northeastern brazilian Coastal Plains. Ciência e Agrotecnologia 36: 507-517.

Silva, S.H.G.; Teixeira, A.F.S.; Menezes, M.D.; Guilherme, L.R.G.; Moreira, F.M.S.; Curi, N. 2017. Multiple linear regression and random forest to predict and map soil properties using data from portable X-ray fluorescence analyzer (pXRF). Ciência e Agrotecnologia 41: 648-664.

Silva, S.H.G.; Silva, E.A.; Poggere, G.C.; Guilherme, L.R.G.; Curi, N. 2018. Tropical soils characterization at low cost and time using portable X-ray fluorescence spectrometer (pXRF): effects of different sample preparation methods. Ciência e Agrotecnologia 42: 80-92.

Soil Survey Staff. 2014. Keys to Soil Taxonomy, 12ed. USDANatural Resources Conservation Service, Washington, DC, USA.

Souza, E.; Inácio, E.; Filho, F.; Ernesto, C.; Reynaud, G.; Batjes, N.H. 2016. Pedotransfer functions to estimate bulk density from soil properties and environmental covariates: Rio Doce basin. Scientia Agricola 73: 525-534.

Stockmann, U.; Cattle, S.R.; Minasny, B.; McBratney, A.B. 2016. Utilizing portable X-ray fluorescence spectrometry for in-field investigation of pedogenesis. Catena 139: 220-231.

Vasconcelos, F.C.W.; Carvalho, S.A.; Silva, S.H.G., Silva, E. A., Guerreiro, M.C.; Curi, N. 2013. MACRO simulator (Version 5.0) for predicting atrazine herbicide behavior in Brazilian Latosols. Ciência e Agrotecnologia 37: 211-220.

Weindorf, D.C.; Bakr, N.; Zhu, Y. 2014. Advances in portable $\mathrm{X}$-ray fluorescence (PXRF) for environmental, pedological, and agronomic application. Advances in Agronomy 128: 1-45.

Weindorf, D.C.; Chakraborty, S. 2016. Portable X-ray fluorescence spectrometry analysis of soils. Methods of Soil Analysis. DOI: 10.2136/methods-soil.2015.0033.

Zhu, Y.; Weindorf, D.C.; Zhang, W. 2011. Characterizing soils using a portable X-ray fluorescence spectrometer. 1. Soil texture. Geoderma 167-168: 167-177. 